Changes in Stratigraphic Nomenclature by the U.S. Geological Survey, 1970

GEOLOGICAL SURVEY BULLETIN 1354-A 


\section{Changes in Stratigraphic Nomenclature by the U.S. Geological Survey, 1970}

By GEORGE V. COHEE, ROBERT G. BATES, and WILNA B. WRIGHT CONTRIBUTIONS TO STRATIGRAPHY

GEOLOGICAL SURVEY BULLETIN 1354-A 


\section{UNITED STATES DEPARTMENT OF THE INTERIOR}

\section{ROGERS C. B. MORTON, Secretary}

\section{GEOLOGICAL SURVEY}

W. A. Radlinski, Acting Director

Library of Congress catalog-card No. 76-169079

For sale by the Superintendent of Documents, U.S. Government Printing Office Washington, D.C. 20402 - Price 30 cents Stock Number 2401-1186 


\section{CONTENTS}

\begin{tabular}{lr} 
Listing of nomenclatural changes & A1 \\
The Mifflintown Formation of Middle Silurian age, Bedford & \\
County, Pennsylvania, by Wallace de Witt, Jr - & 28 \\
New age assignments in the stratigraphy of the Glass Mountains, & \\
western Texas, by G. A. Cooper and R. E. Grant & 30 \\
\hline
\end{tabular}

III 



\section{CONTRIBUTIONS TO STRATIGRAPHY}

\section{CHANGES IN STRATIGRAPHIC NOMENCLATURE BY THE U.S. GEOLOGICAL SURVEY, 1970}

By George V. Cohee, Robert G. Bates, and Wilna B. Wright

\section{LISTING OF NOMENCLATURAL CHANGES}

In the following table, stratigraphic names adopted, revised, reinstated, or abandoned are listed alphabetically. The age of the unit, the revision, and the area involved, along with the author's name and date of publication of the report, are given. The publications in which the changes in nomenclature were made are listed in the references at the end of this publication. The capitalization of age terms in the age column follows official usage. 


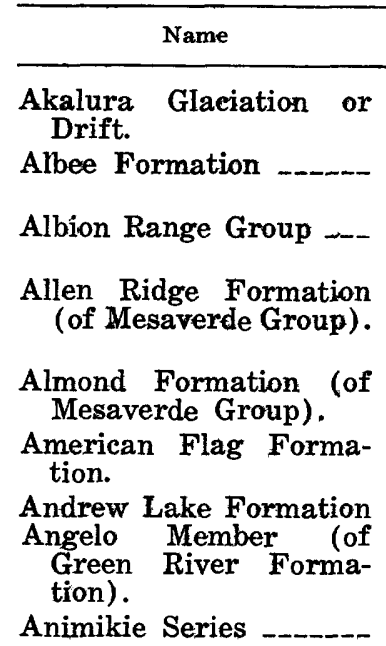

Ashlock Formation

Bakers Bridge Granite Baraga Group

Barstow Formation

Bashi Marl Member (of Hatchetigbee Formation of Wilcox Group).

Baxter Springs Member (of Boone Formation).

Beidell Quartz Latite --

Belden Formation

Belt Supergroup Ben Hur Limestone

Bethlehem Gneiss

Bickford Granite

Big Basin Sandstone --Bingham Mine Formation.

Bingham Quartzite

Boehls Butte Formation (of Belt Supergroup).

Bonanza Latite

Boone Formation

\section{Age}

Pleistocene

Middle Ordovician

Precambrian(?)

Late Cretaceous

Late Cretaceous

Late Cretaceous

middle or late Eocene.

Eocene

middle Precambrian --

Late Ordovician

Precambrian

middle Precambrian --

late Miocene

Eocene

Late Mississippian _---

Oligocene

Early (Morrow) and Middle (Atoka) Pennsylvanian.

Precambrian

Middle Ordovician

Early (?) Devonian ---

Middle(?) and Late(?) Devonian.

Permian

Late Pennsylvanian (Missouri and Virgil).

Pennsylvanian

Precambrian

Oligocene

Early and Late Mississippian.
Location

Alaska

Vermont and New Hampshire.

Utah

South-central Wyoming.

Southwestern

Wyoming.

Arizona

Southwestern Alaska -

Southwestern Wyoming.

Northern Michigan and northern Wisconsin.

Central Kentucky

Southwestern Colorado Northern Michigan and northern Wisconsin.

Southern California --

Mississippi

Oklahoma and Kansas_

Southwestern Colorado

Colorado

Idaho

Eastern Tennessee

New Hampshire

New Hampshire

Southwestern Kansas North-central Utah .--

North-central Utah _.--

Idaho

Southwestern Colorado Oklahoma and Kansas_ 
Revision and reference

Akalura Glaciation or Drift adopted. (Karlstrom, 1969.)

Age changed from Ordovician to Middle Ordovician. (Cady, 1969.)

Albion Range Group extended into Curlew Valley, northwestern Utah. (Bolke and Price, 1969.)

Allen Ridge Formation of Bergstrom (1959) adopted in Hanna and Carbon basins. Overlies Haystack Mountains Formation (new); unconformably underlies Pine Ridge Sandstone. (Gill and others, 1970.)

Almond Formation extended into south-central Wyoming. (Gill and others, 1970.)

Age changed from Cretaceous (?) to Late Cretaceous. (Hayes, 1970a.)

Andrew Lake Formation adopted. (Scholl and others, 1970.)

Angelo Member adopted. (Oriel and Tracey, 1970.)

Animikie Series abandoned in northern Michigan and northern Wisconsin; replaced by Marquette Range Supergroup. Animikie Group remains in good usage in northern Minnesota. (Cannon and Gair, 1970.)

Tate member of Ashlock Formation in central Kentucky extended into northeastern Kentucky as Tate Member of Grant Lake Limestone. (Outerbridge, 1970.)

Bakers Bridge Granite adopted. (Barker, 1969.)

Baraga Group removed from Animikie Series (abandoned) and placed in Marquette Range Supergroup (new). (Cannon and Gair, 1970.)

Age changed from middle and late Miocene to late Miocene. (Lewis, 1968.)

Bashi Marl Member of Hatchetigbee Formation of Wilcox Group used in central Mississippi. Previously Wilcox Group had not been differentiated in this area. (Cushing and others, 1970.)

Baxter Springs Member adopted. (McKnight and Fischer, 1970.)

Age changed from Miocene(?) to Oligocene. (Lipman and others, 1970.)

Age changed from Pennsylvanian to Early (Morrow) and Middle (Atoka) Pennsylvanian. (Mutschler, 1970.)

Includes Boehls Butte Formation in report area. (Hietanen, 1968.)

Ben Hur Limestone changed to Ben Hur Formation in this quadrangle. (Harris and Mixon, 1970.)

Age changed from Late Devonian(?) to Early (?) Devonian. (Cady, 1969.) Age changed from Late Devonian(?) to Middle(?) and Late(?) Devonian. (Cady, 1969.)

Big Basin Sandstone of Cragin (1896) adopted. (Meyer and others, 1970.)

Bingham Mine Formation of Welsh and James (1961) adopted as uppermost of three formations in Oquirrh Group in Bingham sequence (central and southern Oquirrh Mountains). Includes (in ascending order): Clipper Ridge and Markham Peak Members (both new). Overlies Butterfield Peak Formation (new). (Tooker and Roberts, 1970.)

Bingham Quartzite abandoned. Rocks at its type locality reassigned to part of Oquirrh Group. (Tooker and Roberts, 1970.)

Boehls Butte Formation adopted. Includes units formerly considered lowest exposed part of Prichard Formation in Boehls Butte area. (Hietanen, 1968.)

Age changed from Tertiary to Oligocene. (Lipman and others, 1970.)

Boone Formation in Picher field area divided into the following members (in ascending order): St. Joe Limestone, Reeds Spring, Grand Falls, Joplin (new), Short Creek, Baxter Springs (new), and Moccasin Bend. (McKnight and Fischer, 1970.) 


\begin{tabular}{|c|c|c|}
\hline Name & Age & Location \\
\hline Borden Formation & $\begin{array}{l}\text { Early and Late Missis- } \\
\text { sippian. }\end{array}$ & Kentucky - \\
\hline Brezee Phyllite _. & Early Cambrian & Vermont ___ \\
\hline Bright Angel Shale _-_- & $\begin{array}{l}\text { Early and Middle Cam- } \\
\text { brian. }\end{array}$ & $\begin{array}{l}\text { Southeastern California } \\
\text { and southern Nevada. }\end{array}$ \\
\hline Brimfield Schist _-_-_- & $\begin{array}{l}\text { Middle (?) Ordovician } \\
\text { or older. }\end{array}$ & Connecticut _._. \\
\hline $\begin{array}{l}\text { Browns Canyon Forma- } \\
\text { tion. }\end{array}$ & Miocene & Colorado \\
\hline Browns Park Formation & $\begin{array}{l}\text { Miocene and Pliocene } \\
(?) .\end{array}$ & $\begin{array}{l}\text { Utah, Colorado, and } \\
\text { Wyoming. }\end{array}$ \\
\hline $\begin{array}{l}\text { Buckhorn Conglomerate } \\
\text { Member (of Cedar } \\
\text { Mountain Formation). }\end{array}$ & Early Cretaceous _... & Utah and Colorado \\
\hline $\begin{array}{l}\text { Buffalo Wallow Forma- } \\
\text { tion. }\end{array}$ & Late Mississippian --- & Kentucky _._. \\
\hline
\end{tabular}

Bug Formation

Bulldog Hollow Member (of Fowkes Formation).

Bull Fork Formation ---

Bullpen Member (of Wasatch Formation).

Butterfield Limestone Member (of Bingham Quartzite).

Butterfield Peaks Formation.

Caballo Blanco Rhyolite Tuff Member (of Datil Formation).

Catoctin Formation

Cedar Mountain Formation.

Chiapuk Rhyolite

Chocolay Group

Cinnamon Ridge Member (of Flat Ridge Formation).

Circle Volcanics

Clarno Formation

Clipper Ridge Member (of Bingham Mine Formation).
Pliocene or Pleistocene Eocene

Late Ordovician

Eocene

Pennsylvanian

Middle Pennsylvanian_

Oligocene

Precambrian

Early Cretaceous

Late Cretaceous middle Precambrian

Wyoming

Southwestern

Wyoming.

Northeastern Kentucky

Southwestern

Wyoming.

North-central Utah _-_-

North-central Utah _...

Southwestern

New Mexico.

West Virginia, Virginia, Pennsylvania, and Maryland.

Utah and Colorado -..-

Arizona

Northern Minnesota

and

northern Wisconsin.

Precambrian

North Carolina, Virginia, and

Tennessee.

upper Paleozoic

East-central Alaska -.

Eocene and early Oli- Oregon gocene.

Late Pennsylvanian _- North-central Utah _-_ 
Revision and reference

Farmers Siltstone Member of New Providence Formation of Stockdale (1939) redefined and adopted as Farmers Member of Borden Formation. Includes Henley Bed at base. (Peck, 1969.)

Name changed from Brezee Phyllite to Brezee Formation. (Cady, 1969.)

Age changed from Middle Cambrian to Early and Middle Cambrian in southern Nevada and southeastern California; age remains Middle Cambrian in Arizona. (Stewart, 1970.)

Daly Swamp Member (new) of Brimfield Schist adopted. (Snyder, 1970.)

Browns Canyon Formation adopted. (Van Alstine, 1969.)

Age changed from Miocene(?) to Miocene and Pliocene(?). (Izett and others, 1970.)

Buckhorn Conglomerate of Stokes (1944) adopted as Buckhorn Conglomerate Member of Cedar Mountain Formation. (Cullins, 1969.)

In north-central Kentucky, Buffalo Wallow Formation includes following members (in ascending order): Vienna Limestone, Waltersburg, Menard Limestone, unnamed unit (includes equivalents of Degonia Sandstone, Clore Limestone, and Palestine Sandstone), and Kinkaid Limestone. (Goudarzi, 1970.)

Bug Formation adopted. (Love, 1970.)

Bulldog Hollow adopted as middle member. Overlies Sillem Member (new); underlies Gooseberry Member (new). (Oriel and Tracey, 1970.)

Sunset Member of Arnheim Formation of Foerste (1912) adopted as Sunset Member of Bull Fork Formation. (Outerbridge, 1970.)

Bullpen Member adopted. (Oriel and Tracey, 1970.)

Butterfield Limestone Member abandoned. Its rocks included in Butterfield Peaks Formation (new). (Tooker and Roberts, 1970.)

Butterfield Peaks Formation adopted as middle formation of three in Oquirrh Group in Bingham sequence (central and southern Oquirrh Mountains). Overlies West Canyon Limestone; underlies Bingham Mine Formation. (Tooker and Roberts, 1970.)

Caballo Blanco Rhyolite Tuff of Elston (1957) adopted as member of Datil Formation. (Ericksen and others, 1970.)

Age changed from late Precambrian(?) to Precambrian. (Espenshade, 1970.)

Cedar Mountain Formation divided into Buckhorn Conglomerate Member and overlying unnamed shale member. (Cullins, 1969.)

Age changed from late(?) Mesozoic to Late Cretaceous. (Hayes, 1970a.)

Chocolay Group removed from Animikie Series (abandoned); placed in Marquette Range Supergroup (new). (Cannon and Gair, 1970.)

Cinnamon Ridge Member abandoned. Its rocks included in Mount Rogers Formation. (Rankin, 1970.)

Age changed from Early Mississippian to late Paleozoic. (Brabb and Churkin, 1969.)

Age changed from Eocene to Eocene and early Oligocene. (Swanson, 1969.)

Clipper Ridge Member adopted as basal member. Recognized in Bingham sequence (central and southern Oquirrh Mountains). Underlies Markham Peak Member (new). (Tooker and Roberts, 1970.) 


\begin{tabular}{l}
\hline Name \\
\hline Cloudburst Formation -- \\
Cocoraque Formation -- \\
Cody Shale \\
Commercial Limestone \\
Member (of Bingham \\
Quartzite).
\end{tabular}

Concepción Formation -

Concord Granite

Conejos Formation

Copper Basin Formation

Corkscrew Quartzite

Cornett Basalt Member (of Flat Ridge Formation).

Coronados Volcanics -.-

Crooks Gap Conglomerate.

Dad Sandstone Member (of Lewis Shale).

Daly Swamp Member (of Brimfield Schist).

Datil Formation

Daylight Formation

Decie Ranch Member (of Skinner Ranch Formation).

Descon Formation

Deseret Limestone

Dry Union Formation --

Dugout Mountain Member (of Skinner Ranch Formation).

Dutton Creek Formation

Echooka Member (of Sadlerochit Formation).

Echooka River Glaciation).

El Capitan Granite

Electra Lake Gabbro -.-

Elk River Beds
Age

Location
Late Cretaceous

Early Cretaceous

Late Cretaceous

Pennsylvanian

Eocene

Middle(?) and Late(?) Devonian.

Oligocene and older(?)

Early Mississippian to Late Pennsylvanian.

Early Cambrian

Precambrian

Middle Devonian

Eocene

Late Cretaceous

Middle(?) Ordovician or older.

Oligocene

Precambrian and Early Cambrian.

Early Permian (Wolfcamp).

Early Ordovician and Early Silurian.

Late Mississippian --Miocene and Pliocene Early Permian (Wolfcamp).

Paleocene

Late Permian

Pleistocene

Late Jurassic

Precambrian

Pliocene or Pleistocene
Arizona

Arizona

Central Wyoming

North-central Utah

Northwestern Puerto Rico.

New Hampshire

Southwestern Colorado

South-central Idaho --

Nevada and California

North Carolina, Virginia, and Tennessee.

Southeastern Alaska --

Wyoming

Wyoming

Connecticut

New Mexico

Nevada and California

Western Texas

Southeastern Alaska --

Utah

Colorado

Western Texas

Wyoming

Northern Alaska

Northern Alaska

Eastern California -...

Southwestern Colorado Southwestern Oregon - 
Revision and reference

Age changed from Late(?) Cretaceous or early Tertiary to Late Cretaceous. (Hayes, 1970a.)

Age changed from Mesozoic to Early Cretaceous. (Hayes, 1970a.)

Wallace Creek Tongue adopted as upper member of Cody Shale. Separated from main body of Cody by Fales Sandstone Member of Mesaverde Formation. (Gill and others, 1970.)

Commercial Limestone Member abandoned. Its rocks included in Bingham Mine Formation. (Tooker and Roberts, 1970.)

Concepción Formation adopted. Underlies Mal Paso Formation (new). (McIntyre and others, 1970.)

Age changed from Late Devonian(?) to Middle(?) and Late(?) Devonian. (Cady, 1969.)

Age changed from Oligocene or older to Oligocene and older(?). (Lipman and others, 1970.)

Age changed from Early Mississippian to Early Permian to Early Mississippian to Late Pennsylvanian. (Nelson and Ross, 1969.)

Corkscrew Quartzite abandoned. Its rocks reassigned to Zabriskie Quartzite. (Stewart, 1970.)

Cornett Basalt Member abandoned. Its rocks included in Mount Rogers Formation. (Rankin, 1970.)

Coronados Volcanics adopted. (Eberlein and Churkin, 1970.)

Crooks Gap Conglomerate adopted. (Love, 1970.)

Dad Sandstone Member of Hale (1961) adopted. (Gill and others, 1970.)

Daly Swamp Member adopted. (Snyder, 1970.)

Caballo Blanco Rhyolite Tuff and Kneeling Nun Tuff made members of Datil Formation in Black Range area. Age changed from Tertiary to Oligocene. (Ericksen and others, 1970.)

Daylight Formation abandoned. Its rocks reassigned to Wood Canyon Formation. (Stewart, 1970.)

Age changed from Early Permian (Leonard) to Early Permian (Wolfcamp). (Cooper and Grant, this report, p. A30.)

Descon Formation adopted. Underlies Heceta Limestone (new). (Eberlein and Churkin, 1970.)

Deseret Limestone extended into northeastern Utah. (Hansen, 1969.)

Age changed from Pliocene to Miocene and Pliocene. (Van Alstine, 1969.)

Age changed from Early Permian (Leonard) to Early Permian (Wolfcamp). (Cooper and Grant, this report, p. A30.)

Dutton Creek Formation is coarse-grained conglomerate facies of Hanna Formation; Dutton Creek Formation therefore abandoned. (Gill and others, 1970.)

Age changed from Permian to Late Permian. (Detterman, 1970b.)

Echooka River Glaciation abandoned; considered equivalent to Itkillik Glaciation which name will now be used. (Detterman, 1970a.)

Age changed from Cretaceous to Late Jurassic. (Evernden and Kistler, 1970.) Electra Lake Gabbro adopted. (Barker, 1969.)

Type Elk River Beds restricted to those beds in the type section below a wave-cut platform. Age changed from late Pleistocene to Pliocene or Pleistocene. (Clifton and Boggs, 1970.) 


\begin{tabular}{l}
\hline Name \\
\hline Erda Formation \\
Escabrosa Limestone --- \\
Evanston Formation --- \\
Fales Sandstone Mem- \\
ber (of Mesaverde \\
Formation).
\end{tabular}

Farmers Member (of Borden Formation).

Fearn Springs Member (of Nanafalia Formation of Wilcox Group).

Finger Bay Volcanics --

Fish Creek Mountains Tuff.

Flat Ridge Formation (of Mount Rogers Volcanic Group).

Foote Creek Formation -

Fossil Butte Member (of Green River Formation).

Fowkes Formation

\section{Age}

Location

Middle Pennsylvanian (Atoka and Des Moines).

Early and Late Mississippian.

Late Cretaceous and Paleocene.

Late Cretaceous

Central Wyoming

Mississippian

Eastern Kentucky

Eocene

Mississippi

early Tertiary

Southwestern Alaska -

early Miocene

Central Nevada

Precambrian
North Carolina,
Virginia, and
Tennessee.

Late Cretaceous and Paleocene.

Eocene

Wyoming

Southwestern Wyoming

Eocene to Pliocene(?) -

Southwestern Wyoming

Frederika Formation --

Miocene

Freeman Silt

early Miocene (early Saucesian).

French Pond Granite -- Middle(?) and Late(?) Devonian.

Gaptank Formation _...-

Gem Park Complex

Middle and Late Pennsylvanian and Early Permian (Wolfcamp).

Gile Mountain Formation.

Glastonbury Gneiss ----

Glorieta Sandstone

Cambrian

Early Devonian

Devonian or Mississippian.

Early Permian (late Eeonard).

Golden Horn Limestone Lentil (of Hasen Creek

Early Permian

Alaska

California

New Hampshire

Western Texas

Colorado

Vermont and New Hampshire.

Connecticut

New Mexico

Alaska

Formation) (of Skolai Group).

Gooseberry Member (of Fowkes Formation).

Grainger Formation

Pliocene

Southwestern Wyoming

Early Mississippian -- 
Revision and reference

Erda Formation adopted as middle formation of three in Oquirrh Group in Rogers Canyon sequence (northern Oquirrh Mountains). Overlies Lake Point Limestone (new); underlies Kessler Canyon Formation (new). (Tooker and Roberts, 1970.)

Escabrosa Limestone raised to group rank in southeastern Arizona and southwestern New Mexico; includes (in ascending order) : Keating and Hachita Formations, Remains of formation rank elsewhere. (Armstrong, 1970.)

Evanston Formation divided into lower member and Hams Fork Conglomerate Member (new) (Upper Cretaceous) and upper unit (Upper Cretaceous and Paleocene). (Oriel and Tracey, 1970.)

Fales Sandstone Member of Barwin (1961) adopted as basal member of Mesaverde Formation in southeastern Wind River basin. (Gill and others, 1970.)

Henley Bed adopted as basal unit of Farmers Member of Borden Formation. (Peck, 1969.)

Fearn Springs Member of Nanafalia Formation of Wilcox Group used in central Mississippi. Previously Wilcox Group had not been differentiated in this area. (Cushing and others, 1970.)

Age changed from Tertiary (?) to early Tertiary. (Scholl and others, 1970.)

Fish Creek Mountains Tuff adopted. (McKee, 1970.)

Flat Ridge Formation abandoned. Its rocks included in Mount Rogers Formation. (Rankin, 1970.)

Foote Creek Formation abandoned. Its rocks are lower or coal-bearing parts of Medicine Bow and Hanna Formations. (Gill and others, 1970.)

Fossil Butte Member adopted. (Oriel and Tracey, 1970.)

Fowkes Formation divided into three members (in ascending order) : Sillem and Bulldog Hollow (both Eocené) and Gooseberry (Eocene (?) to Pliocene(?)) (all three new). Age changed from late Eocene to Eocene to Pliocene (?). (Oriel and Tracey, 1970.)

Frederika Formation adopted. (MacKevett, 1970.)

Freeman Silt of Kleinpell (1938) adopted. Overlies Jewett Sand; underlies Olcese Sand. (Addicott, 1970.)

Age changed from Late Devonian(?) to Middle(?) and Late(?) Devonian. (Cady, 1969.)

Upper part of Gaptank Formation placed in Wolfcamp Series. (Cooper and Grant, this report, p. A30.)

Gem Park Complex adopted. (Parker and Sharp, 1970.)

Age changed from Devonian to Early Devonian. (Cady, 1969.)

Glastonbury Gneiss of Gregory (1906) adopted. (Snyder, 1970.)

Age changed from Permian to Early Permian (late Leonard) in Fort Wingate area. (Ash, 1969.)

Golden Horn Limestone Lentil adopted. (Smith and MacKevett, 1970.)

Gooseberry adopted (provisionally assigned) as upper member. Overlies Bulldog Hollow Member (new). (Oriel and Tracey, 1970.)

Outcrop of Grainger Formation extended into southeastern Kentucky; previously known in southeastern Kentucky in subsurface only. (Csejtey, 1970). 


\begin{tabular}{lll}
\hline Name & Age & Location \\
\hline
\end{tabular}

Grand Falls Chert Member (of Boone Formation).

Granite Creek Granodiorite.

Grant Lake Limestone -

Green Ravine Formation

Green River Formation_

Guacio Member (of Río Culebrinas Formation).

Hachita Formation (of Escabrosa Group).

Half Dome Quartz Monzonite.

Halfway Draw Tuff Member (of Wind River Formation).

Hams Fork Conglomerate Member (of Evanston Formation).

Hanna Formation

Hartford Hill Rhyolite Tuff.

Hartselle Sandstone -..--

Hasen Creek Formation (of Skolai Group).

Hatchetigbee Formation

Hatfield Sandstone Member (of Haystack Mountains Formation) (of Mesaverde Group).

Hawi Volcanic Series --

Hayden Creek Drift (of Salmon Springs Glaciation).

Haystack Mountains Formation (of Mesaverde Group).

Hebron Formation

Heceta Limestone
Early Mississippian

Oklahoma and Kansas_

Cretaceous

Idaho

Late Ordovician

Northeastern Kentucky

Late Mississippian

North-central Utah

Eocene

Southwestern Wyoming

middle Eocene

Northwestern Puerto Rico.

Early and Late Mississippian.

Late Cretaceous

early Eocene

-...-

Southwestern New Mexico and southeastern Arizona.

Eastern California ---

Wyoming

Late Cretaceous

Southwestern Wyoming

Paleocene

Wyoming

early Miocene

Western Nevada

Late Mississippian

Southeastern Kentucky

Early Permian

Alaska

Eocene

Mississippi

Late Cretaceous

Wyoming

late Pleistocene

Hawaii

Pleistocene

Washington

Late Cretaceous

South-central Wyoming
Ordovician or older

Connecticut

Middle and Late Sil- Southeastern Alaska -urian. 
Revision and reference

Age changed from Mississippian to Early Mississippian. (McKnight and Fischer, 1970.)

Age changed from Jurassic or Cretaceous to Cretaceous. (King and others, 1970.)

Tate Member of Ashlock Formation in central Kentucky extended into northeastern Kentucky as Tate Member of Grant Lake Limestone. (Outerbridge, 1970.)

Green Ravine Formation adopted. Recognized in Rogers Canyon sequence (northern Oquirrh Mountains). Underlies Oquirrh Group. (Tooker and Roberts, 1970.)

Green River Formation in Fossil Basin divided into two members (in ascending order ): Fossil Butte and Angelo Members (both new). (Oriel and Tracey, 1970.)

Guacio Member adopted. Underlies Maricao Basalt. (McIntyre and others, 1970.)

Hachita Formation of Armstrong (1962) adopted as upper formation of Escabrosa Group. (Armstrong, 1970.)

Age changed from Cretaceous to Late Cretaceous. (Evernden and Kistler, 1970.)

Halfway Draw Tuff Member adopted. (Love, 1970.)

Hams Fork Conglomerate Member adopted. (Oriel and Tracey, 1970.)

Age changed from Eocene to Paleocene; restricted to Hanna and Carbon basins. (Gill and others, 1970.)

Age changed from Oligocene(?) to early Miocene. (Moore, 1969.)

Hartselle Sandstone changed to Hartselle Formation in southeastern Kentucky. (Lewis and Luft, 1970.)

Hasen Creek adopted as upper of two formations in Skolai Group (new). Overlies Station Creek Formation (new). Includes Golden Horn Limestone Lentil (new). (Smith and MacKevett, 1970.)

Hatchetigbee Formation of Wilcox Group used in central Mississippi. Previously Wilcox Group had not been differentiated in this area. Includes Bashi Marl Member. (Cushing and others, 1970.)

Hatfield Sandstone Member of Hale (1961) adopted as uppermost named member of Haystack Mountains Formation in Hanna and Carbon basins. (Gill and others, 1970.)

Age changed from Pliocene and early and middle Pleistocene to late Pleistocene. (McDougall, 1969.)

Hayden Creek Drift adopted. (Crandell, 1969.)

Haystack Mountains Formation adopted as basal formation of Mesaverde Group in Hanna and Carbon basins. Includes (in ascending order): Tapers Ranch Sandstone Member, lower unnamed member, O'Brien Spring Sandstone Member, middle unnamed member, Hatfield Sandstone Member, and upper unnamed member. (Gill and others, 1970.)

Age changed from Early Devonian or older to Ordovician or older. (Snyder, 1970.)

Heceta Limestone adopted. Overlies Descon Formation (new) ; underlies Karheen Formation (new). (Eberlein and Churkin, 1970.) 


\begin{tabular}{l} 
Name \\
\hline Heceta Limestone \\
Hempfield Shale ---- \\
Henley Bed (of Farmers \\
Member). \\
Hidalgo Volcanics ----- \\
Highland Boy Limestone \\
Member (of Bingham \\
Quartzite). \\
Highlandcroft Plutonic \\
Series. \\
Hines Tongue (of Reed \\
Dolomite). \\
Hinsdale Formation ---- \\
Hite Bed of Church Rock \\
Member (of Chinle \\
Formation). \\
Hoosac Formation ---.-
\end{tabular}

Horquilla Limestone -..-

Horseshoe Mesa Member (of Redwall Limestone).

House Limestone (of Pogonip Group).

Huachuca Quartz Monzonite.

Humbug Formation

Hurrah Slate

Ice Point Conglomerate_ Irving Greenstone

Jewett Sand

John Day Formation _..-

Jones Ridge Limestone -

Joplin Member (of Boone Formation).

Jordan Limestone Member (of Bingham Quartzite).
Early through Late Silurian.

Mississippian

Mississippian

Late Cretaceous

Pennsylvanian

Middle or Late Ordovician.

Precambrian

Miocene and Pliocene -

Late Triassic

Early Cambrian or older.

Early, Middle, and Late Pennsylvanian.

Late Mississippian (Meramec and Chester).

Late Cambrian and Early Ordovician.

Jurassic

Late Mississippian

Precambrian

Eocene

Precambrian

lower Miocene

middle Oligocene to early Miocene.

Early Cambrian to Middle or Late Ordovician.

Early Mississippian _-

Pennsylvanian
New Mexico

North-central Utah

California

Oregon

East-central Alaska --

Location

Southeastern Alaska --

Pennsylvania and Ohio

Eastern Kentucky -.-.

New Hampshire

Southern Nevada

New Mexico and Colorado.

Northeastern Arizona -

Massachusetts, Connecticut, and Vermont.

Southwestern New Mexico and southeastern Arizona.

Arizona

Western Utah and eastern Nevada.

Arizona

Utah

Northwestern Alaska -

Wyoming

Southwestern Colorado

Oklahoma and Kansas

North-central Utah _-- 
Revision and reference

Age changed from Middle and Late Silurian to Early through Late Silurian. (Ovenshine and Webster, 1970.)

Hempfield Shale abandoned; now upper unnamed member of Shenango Formation. (Kimmel and Schiner, 1970.)

Henley Shale Member of New Providence Formation as used by Stockdale (1939) adopted as Henley Bed, basal unit of Farmers Member of Borden Formation. (Peck, 1969.)

Age changed from Early Cretaceous to Late Cretaceous. (Hayes, 1970a.)

Highland Boy Limestone Member abandoned. Its rocks included in Bingham Mine Formation. (Tooker and Roberts, 1970.)

Age changed from Late Ordovician to Middle or Late Ordovician. (Cady, 1969.)

Hines Tongue extended into southern Nevada. (Stewart, 1970.)

Age changed from late Tertiary to Miocene and Pliocene. (Lipman and others, 1970.)

Hite Bed extended into northeastern Arizona. (O'Sullivan, 1970.)

Age changed from Early(?) Cambrian to Early Cambrian or older. (Hatch, 1969.)

Horquilla Limestone extended into southwestern New Mexico. Age in report area is Early Pennsylvanian. (Armstrong, 1970.)

Age changed from Mississippian to Late Mississippian (Meramec and Chester). (McKee and Gutschick, 1969.)

House Limestone of Hintze (1951) adopted as lowermost formation of Pogonip Group and extended from its type area, western Utah, into southern Snake Range, east-central Nevada. (Whitebread, 1969.)

Age changed from Jurassic(?) to Jurassic. (Hayes, 1970b.)

Humbug Formation extended into northeastern Utah. (Hansen, 1969.)

Age changed from post-Ordovician(?) to Precambrian. (Sainsbury and others, 1970.)

Ice Point Conglomerate adopted. (Love, 1970.)

Irving Greenstone changed to Irving Formation. Also includes Archean schist and gneiss of Cross, Howe, Irving, and Emmons (1905), in southwestern and northern Needle Mountains. (Barker, 1969.)

Jewett zone designated by Godde (1928) adopted as Jewett Sand. Includes Pyramid Hill Sand Member at its base. Overlies Vedder Sand (when present) or Walker Formation; underlies Freeman Silt. (Addicott, 1970.)

Age changed from late Oligocene and early Miocene to middle Oligocene to early Miocene. (Swanson, 1969.)

Age changed from Cambrian to Middle or Late Ordovician to Early Cambrian to Middle or Late Ordovician. (Brabb and Churkin, 1969.)

Joplin Member adopted. (McKnight and Fischer, 1970.)

Jordan Limestone Member abandoned. Its rocks included in Bingham Mine Formation. (Tooker and Roberts, 1970.) 


\begin{tabular}{|c|c|}
\hline Name & Age \\
\hline $\begin{array}{l}\text { Kanosh Shale (of Pogo- } \\
\text { nip Group). }\end{array}$ & Middle Ordovician \\
\hline Karheen Formation _..-- & $\begin{array}{l}\text { Eate Silurian and } \\
\text { Early Devonian. }\end{array}$ \\
\hline $\begin{array}{l}\text { Karluk Glaciation or } \\
\text { Drift. }\end{array}$ & Pleistocene \\
\hline Katakturuk Dolomite -- & $\begin{array}{l}\text { Middle Devonian or } \\
\text { older. }\end{array}$ \\
\hline $\begin{array}{l}\text { Keating Formation (of } \\
\text { Escabrosa Group). }\end{array}$ & Early Mississippian \\
\hline $\begin{array}{l}\text { Keechelus Andesitic } \\
\text { Series. }\end{array}$ & Eocene to Miocene \\
\hline $\begin{array}{l}\text { Kekiktuk Conglomerate } \\
\text { (of Endicott Group). }\end{array}$ & Mississippian \\
\hline $\begin{array}{l}\text { Kessler Canyon Forma- } \\
\text { tion (of Oquirrh } \\
\text { Group). }\end{array}$ & $\begin{array}{l}\text { Late Pennsylvanian } \\
\text { (Virgil) and Early } \\
\text { Permian(?) (Wolf- } \\
\text { camp?). }\end{array}$ \\
\hline
\end{tabular}

Kinsman Quartz Monzonite.

Klawak Formation _-_-_ Early and Middle

Kneeling Nun Tuff _-.--

Kneeling Nun Tuff _.---

Ladrones Limestone ---

La Jara Canyon Member (of Treasure Mountain Tuff).

Lake Fork Formation --

Lake Point Limestone (of Oquirrh Group).

Lamarck Granodiorite -

Lead Camp Limestone --

Lehman Formation (of Pogonip Group).

Oligocene

Oligocene

\section{Early and Middle} Pennsylvanian.

Oligocene

Location

Eastern Nevada and western Utah.

Southeastern Alaska --

Alaska

Northeastern Alaska --

Southeastern Arizona and southwestern New Mexico.

Washington

Northeastern Alaska --

North-central Utah _---

Northwestern Alaska -

New Hampshire

Southeastern Alaska --

New Mexico

Southwestern New Mexico.

Southeastern Alaska --

Colorado

Oligocene and older(?)

Southwestern Colorado

Late Mississippian and Early Pennsylvanian.

North-central Utah _--

Late Cretaceous

Eastern California ---

Middle Pennsylvanian

(Des Moines).

Middle Ordovician -.---

New Mexico

Western Utah and eastern Nevada.

Lenox Limestone Member (of Bingham Quartzite).

Lewis Shale

Pennsylvanian

North-central Utah _---

Late Cretaceous

Central Wyoming -.--

Lisburne Group

Early and Late Mississippian.

Northern Alaska 
Revision and reference

Kanosh Shale of Hintze (1951) adopted and included in Pogonip Group. Underlies Lehman Formation. Extended from its type area, western Nevada, into southern Snake Range, east-central Nevada. (Whitebread, 1969.)

Karheen Formation adopted. Overlies Heceta Limestone (new): (Eberlein and Churkin, 1970.)

Karluk Glaciation or Drift adopted. (Karlstrom, 1969.)

Katakturuk Dolomite adopted. Underlies Nanook Limestone (new). (Dutro, 1970.)

Keating Formation of Armstrong (1962) adopted as lower formation of Escabrosa Group. (Armstrong, 1970.)

Keechelus Andesitic Series abandoned. Its rocks designated by informallynamed stratigraphic unit. (Vine, 1969.)

Age changed from Late(?) Devonian or Mississippian to Mississippian. (Reiser, 1970.)

Kessler Canyon Formation adopted as uppermost of three formations in Oquirrh Group in Rogers Canyon sequence (northern Oquirrh Mountains). Overlies Erda Formation (new); underlies Park City Formation. (Tooker and Roberts, 1970.)

Age changed from Devonian(?) to Precambrian. (Sainsbury and others, 1970.)

Age changed from Late Devonian(?) to Early(?) Devonian. (Cady, 1969.)

Klawak Formation adopted. (Eberlein and Churkin, 1970.)

Age changed from Miocene(?) to Oligocene. (Jones and others, 1970.)

Kneeling Nun Tuff made a member of Datil Formation in Black Range area, southwestern New Mexico. Remains of formation rank elsewhere. (Ericksen and others, 1970.)

Ladrones Limestone adopted. (Eberlein and Churkin, 1970.)

La Jara Canyon Member adopted. (Lipman and Steven, 1970.)

Age changed from Oligocene or older to Oligocene and older(?). (Lipman and others, 1970.)

Lake Point Limestone adopted as lowermost of three formations in Oquirrh Group in Rogers Canyon sequence (northern Oquirrh Mountains). Overlies Green Ravine Formation (new); underlies Erda Formation (new). (Tooker and Roberts, 1970.)

Age changed from Cretaceous to Late Cretaceous. (Evernden and Kistler, 1970.)

Age changed from Pennsylvanian to Middle Pennsylvanian (Des Moines). (Bachman and Harbour, 1970.)

Lehman Formation of Hintze (1951) adopted as uppermost formation, locally, of Pogonip Group. Overlies Kanosh Shale. Extended from its type area, western Utah, into southern Snake Range, east-central Nevada. (Whitebread, 1969.)

Lenox Limestone Member abandoned. Its rocks included in Butterfield Peaks Formation (new). (Tooker and Roberts, 1970.)

Lewis Shale divided into lower part, Dad Sandstone Member, and upper part in Hanna and Carbon basins. (Gill and others, 1970.)

In central and eastern Brooks Range age changed from Early and Late Mississippian, Pennsylvanian(?) and Permian to Early Mississippian (Osage) to Middle Pennsylvanian (Atoka). Elsewhere it is Early and Late Mississippian. (Armstrong and others, 1970.) 


\begin{tabular}{|c|c|c|}
\hline Name & Age & Location \\
\hline Littleton Formation ---- & $\begin{array}{l}\text { Late Silurian(?) and } \\
\text { Early Devonian. }\end{array}$ & $\begin{array}{l}\text { Connecticut, Massa- } \\
\text { chusetts, and New } \\
\text { Hampshire. }\end{array}$ \\
\hline $\begin{array}{l}\text { Livingston Hills Forma- } \\
\text { tion. }\end{array}$ & Cretaceous or Tertiary & Southwestern Arizona - \\
\hline Los Pinos Gravel _...-- & Oligocene to Pliocene - & $\begin{array}{l}\text { New Mexico and } \\
\text { Colorado. }\end{array}$ \\
\hline Lykins Formation -.--- & $\begin{array}{l}\text { Permian and } \\
\text { Triassic(?). }\end{array}$ & Colorado _- \\
\hline Mal Paso Formation --- & Eocene _- & $\begin{array}{l}\text { Northwestern Puerto } \\
\text { Rico. }\end{array}$ \\
\hline Maricao Basalt _._-_-_- & Late Cretaceous _-_--- & $\begin{array}{l}\text { Northwestern Puerto } \\
\text { Rico. }\end{array}$ \\
\hline $\begin{array}{l}\text { Markham Peak Member } \\
\text { (of Bingham Mine } \\
\text { Formation). }\end{array}$ & Late Pennsylvanian -- & North-central Utah \\
\hline $\begin{array}{l}\text { Marquette Range Super- } \\
\text { group. }\end{array}$ & middle Precambrian -- & $\begin{array}{l}\text { Northern Michigan and } \\
\text { northern Wisconsin. }\end{array}$ \\
\hline Matilde Formation _...- & middle Eocene -_-_-_- & Puerto Rico _-_-_-_-_ \\
\hline $\begin{array}{l}\text { McClure Mountain Com- } \\
\text { plex. }\end{array}$ & Cambrian _- & Colorado --.-- \\
\hline $\begin{array}{l}\text { McNeeley Drift (of } \\
\text { Fraser Glaciation) }\end{array}$ & Pleistocene & Washington _._. \\
\hline $\begin{array}{l}\text { Medicine Bow Forma- } \\
\text { tion. }\end{array}$ & Late Cretaceous _...-- & Wyoming - - \\
\hline Menard Limestone _-.--- & Late Mississippian --- & Kentucky _..... \\
\hline
\end{tabular}

Menominee Group _..._ middle Precambrian --

Mesaverde Group _...-.- Late Cretaceous

Northern Michigan and northern Wisconsin.

Wyoming

Mifflintown Formation -

Middle Silurian

South-central

Pennsylvania .

Milagros Formation -..--

Moat Volcanics

middle Eocene

Puerto Rico

Permian (?)

New Hampshire

Moccasin Bend Member (of Boone Formation).

Molas Formation

Late Mississippian

Oklahoma and Kansas

Mississippian and

Early Pennsylvanian (Morrow).

Monmouth Group

Late Cretaceous

Colorado, New Mexico, and Arizona.

New York, Pennsylvania, and New Jersey. 
Revision and reference

Age changed from Early Devonian to Late Silurian(?) and Early Devonian. (Cady, 1969.)

Livingston Hills Formation adopted. (Miller, 1970.)

Los Pinos Gravel changed to Los Pinos Formation; age changed from Miocene and Pliocene(?) to Oligocene to Pliocene. (Lipman and others, 1970.)

Age changed from Permian(?) and Triassic(?) to Permian and Triassic(?). (Scott, 1970.)

Mal Paso Formation adopted. Overlies Concepción Formation (new) ; underlies Rio Culebrinas Formation. (McIntyre and others, 1970.)

Maricao Basalt of Mattson (1960) adopted. Overlies Yauco Mudstone. (McIntyre and others, 1970.)

Markham Peak Member adopted as upper member. Recognized in Bingham sequence (central and southern Oquirrh Mountains). Overlies Clipper Ridge Member (new). (Tooker and Roberts, 1970.)

Marquette Range Supergroup adopted. Includes (in ascending order): Chocolay, Menominee, Baraga, and Paint River Groups. Replaces Animikie Series (abandoned). Animikie Group remains in good usage in northern Minnesota. (Cannon and Gair, 1970.)

Age changed from late Paleocene and Eocene to middle Eocene. (McIntyre and others, 1970.)

Age changed from Precambrian or Cambrian to Cambrian. (Parker and Sharp, 1970.)

McNeeley Drift adopted. (Crandell, 1969.)

Medicine Bow Formation restricted to Hanna, Laramie, and Carbon basins. (Gill and others, 1970.)

Menard Limestone made member of Buffalo Wallow Formation in northcentral Kentucky. Menard Limestone remains in good usage in Illinois and western Kentucky. (Goudarzi, 1970.)

Menominee Group removed from Animikie Series (abandoned) and placed in Marquette Range Supergroup (new). (Cannon and Gair, 1970.)

Mesaverde Formation raised to Mesaverde Group in south-central Wyoming where it is composed of the Haystack Mountains Formation, Allen Ridge Formation, Pine Ridge Sandstone, and Almond Formation. In Laramie basin, group composed only of Rock River Formation and Pine Ridge Sandstone. Mesaverde Formation still recognized in southeastern Wind River basin where divided into Fales Sandstone Member, Parkman Sandstone Member, unnamed middle member, and Teapot Sandstone Member, and in Powder River basin where divided into Parkman Sandstone Member, unnamed marine shale member, and Teapot Sandstone Member. (Gill and others, 1970.)

Mifflintown Formation as used and redefined by Miller and Conlin (in Miller, 1961) adopted. (de Witt, this report, p. A28.)

Age changed from Eocene(?) to middle Eocene. (McIntyre and others, 1970.) Age changed from Late Permian to Permian(?). (Cady, 1969.)

Moccasin Bend Member adopted. (McKnight and Fischer, 1970.)

Age changed from Pennsylvanian to Mississippian and Early Pennsylvanian (Morrow). (Mutschler, 1970.)

Monmouth Group abandoned in Maryland and Delaware; remains in good usage in New Jersey, Pennsylvania, and New York. Monmouth Formation remains in good usage in Maryland near District of Columbia. (Owens and others, 1970.) 


\begin{tabular}{l}
\hline Name \\
\hline Monterey Formation --- \\
Mooney Falls Member \\
(of Redwall Lime- \\
stone). \\
Morales Member (of \\
Santa Margarita For- \\
mation). \\
Mount Rogers Formation
\end{tabular}

Nanafalia Formation (of Wilcox Group).

Nanook Limestone -----

Nathrop Volcanics

Needles Range Formation.

Nelson Mountain Quartz Latite.

New Hampshire Plutonic Series.

Nome Group

Nonesuch Shale

Northfield Formation --

Obispo Tuff Member (of Monterey Formation).

O'Brien Spring Sandstone Member (of Haystack Mountains Formation) (of Mesaverde Group).

Ojito Creek Member (of Treasure Mountain Tuff).

Olcese Sand

Oquirrh Formation

Early and Late

Mississippian

(Meramec and

Osage).

late Miocene

Precambrian

Age

Location

Miocene

California

Arizona

California

North Carolina,

Virginia, and

Tennessee.

Eocene

Middle Devonian

Northeastern Alaska

Late Oligocene

Oligocene

Oligocene

Devonian

Precambrian

Precambrian

Middle(?) Silurian _._-

Miocene

Colorado

Southwestern Utah and eastern Nevada.

Colorado

New Hampshire and Vermont.

Northwestern Alaska -

Michigan and

Wisconsin .

Vermont

California

Late Cretaceous

Wyoming

Oligocene

Colorado

middle Miocene

California

Late Mississippian to Early Permian(?).

North-central Utah

Oquirrh Formation 
Revision and reference

Obispo Tuff Member, basal member of Monterey Formation, removed from Monterey Formation and raised in rank to Obispo Formation following usage of Hall and others (1966). (Turner and others, 1970.)

Age changed from Mississippian to Early and Late Mississippian (Meramec and Osage). (McKee and Gutschick, 1969.)

Morales Member of Santa Margarita Formation raised in rank to Morales Formation. Age changed from late Miocene to Pliocene. (Vedder, 1970.)

Mount Rogers Volcanic Group reduced from group to formation rank and name changed to Mount Rogers Formation. Its former subdivisions, Flat Ridge Formation containing Cinnamon Ridge and Cornett Basalt Members, abandoned and their rocks included in Mount Rogers Formation. (Rankin, 1970:)

Nanafalia Formation of Wilcox Group used in central Mississippi. Previously Wilcox Group had not been differentiated in this area. Includes Fearn Springs Member. (Cushing and others, 1970.)

Nanook Limestone adopted. Overlies Katakturuk Dolomite (new). Dutro, 1970.)

Nathrop Volcanics adopted. (Van Alstine, 1969.)

Needles Range Formation extended into eastern Nevada. Age changed from Eocene or early Oligocene to Oligocene. (Whitebread, 1969.)

Age changed from middle or late Tertiary to Oligocene. (Lipman and others, 1970.)

Age changed from Late Devonian(?) to Devonian. (Cady, 1969.)

Age changed from Silurian and Ordovician to Precambrian. (Sainsbury and others, 1970.)

Nonesuch Shale extended into Wisconsin (northwestern part). (Vine and Tourtelet, 1969.)

Name changed from Northfield Slate to Northfield Formation; age changed from Middle Silurian to Middle(?) Silurian. (Cady, 1969.)

Obispo Tuff Member removed from Monterey Formation and raised in rank to Obispo Formation following usage of Hall and others (1966). (Turner and others, 1970.)

O'Brien Spring Sandstone Member adopted as middle named member of Haystack Mountains Formation. (Gill and others, 1970.)

Ojito Creek Member adopted. (Lipman and Steven, 1970.)

Olcese Sand of Diepenbrock (1933) adopted. Overlies Freeman Silt; underlies Round Mountain Silt. (Addicott, 1970.)

In Oquirrh Mountains, its type area, Oquirrh Formation raised in rank to Oquirrh Goup. Age ranges from Late Mississipian to Early Permian(?). South of Midas thrust, in Bingham sequence, contains (in ascending order) : West Canyon Limestone, Butterfield Peaks Formation, and Bingham Mine Formation. Age there is Early, Middle, and Late Pennsylvanian. North of the North Oquirrh thrust, in the Rogers Canyon sequence, includes (in ascending order): Lake Point Limestone and Erda and Kessler Formations. Age is Late Mississippian to Early Permian(?). Overlies Green Ravine Formation; underlies Park City Formation. (Tooker and Roberts, 1970.)

In Curlew Valley, northwestern Utah, the Oquirrh is of formational rank and of Pennsylvanian and Permian age. (Bolke and Price, 1969.) 


\begin{tabular}{l} 
Name \\
\hline Oreville Formation ---- \\
Packsaddle Mountain \\
Granodiorite. \\
Pahrump Series --_--- \\
Paint River Group ---- \\
Panther Seep Formation \\
Paradise Formation --- \\
Paskenta Formation --- \\
Peratrovich Formation - \\
Perryville Member (of \\
Lexington Limestone). \\
Phoenix Limestone \\
Lentil (of Bingham \\
Quartzite). \\
Pine Ridge Sandstone \\
Member (of Mesaverde \\
Formation). \\
Pinnacle Formation ---- \\
Pioche Shale --..----- \\
Pogonip Group -------
\end{tabular}

Point Pleasant Formation.

Polulu Volcanic Series -

Poplar Tank Member (of Skinner Ranch Formation).

Port Refugio Formation

Potosi Volcanic Group --

Prospect Mountain Quartzite.

Puckmummie Schist

Pyramid Hill Sand Member (of Jewett Sand).

Quapaw Limestone

Rainstorm Member (of Johnnie Formation).

Ra Jadero Member (of Treasure Mountain Tuff).

Rampart Group

Rat Creek Quartz Latite
Precambrian

Cretaceous

late Precambrian

middle Precambrian --

Late Pennsylvanian and Early Permian.

Late Mississippian

Early Cretaceous

Early and Late Mississippian.

Middle Ordovician _..--

Pennsylvanian

Late Cretaceous

Early Cambrian(?) Cambrian

Late Cambrian, Early and Middle Ordovician.

Middle and Late Ordovician.

late Pleistocene

Early Permian (Wolfcamp).

Late Devonian

Oligocene

Precambrian and Early Cambrian.

Precambrian

early Miocene

Late Mississippian -.late Precambrian

Oligocene

Permian (?)

Oligocene
Location

South Dakota

Idaho

Southeastern California

Northern Michigan and northern Wisconsin.

New Mexico

Southeastern Arizona and southwestern New Mexico.

California and Oregon

Southeastern Alaska --

Kentucky

North-central Utah --

Wyoming

Vermont

Northeastern Nevada -

Eastern Nevada and western Utah.

North-central Kentucky

Hawaii

Western Texas

Southeastern Alaska -Southwestern Colorado

Southeastern California and southern Nevada.

Northwestern Alaska -

California

Oklahoma

Southeastern California

Southwestern Colorado

Central Alaska

Colorado 
Revision and reference

Oreville Formation adopted. (Ratte and Wayland, 1969.)

Age changed from probably Jurassic or Cretaceous to Cretaceous. (King and others, 1970.)

Name changed from Pahrump Series to Pahrump Group; definition remains unchanged. (Stewart, 1970.)

Paint River Group removed from Animikie Series (abandoned) and placed in Marquette Range Supergroup (new). (Cannon and Gair, 1970.)

Age changed from Late Pennsylvanian to Late Pennsylvanian and Early Permian. (Bachman and Harbour, 1970.)

Paradise Formation of Stoyanow (1926) adopted. (Armstrong, 1970.)

Paskenta Formation abandoned as it was defined as biostratigraphic unit. (Jones and others, 1969.)

Peratrovich Formation adopted; overlies Wadleigh Limestone (new). (Eberlein and Churkin, 1970.)

Name changed from Perryville Member to Perryville Limestone Member. (Cressman and Hrabar, 1970.)

Phoenix Limestone Lentil abandoned. Its rocks included in Butterfield Peaks Formation (new). (Tooker and Roberts, 1970.)

In Hanna, Carbon, and Laramie basins, Pine Ridge Sandstone Member raised to formation rank in Mesaverde Group. (Gill and others, 1970.)

Age changed from Cambrian(?) to Early Cambrian(?). (Cady, 1969.)

Name changed to Pioche Formation in the Ruby Mountains where the shale is metamorphosed. (Willden and Kistler, 1969.)

Pogonip Group in southern Snake Range includes (in ascending order): House Limestone, an unnamed limestone unit, Lehman Formation, and Kanosh Shale. Age locally is Late Cambrian and Early and Middle Ordovician. (Whitebread, 1969.)

Age changed from Middle Ordovician to Middle and Late Ordovician. (Luft, 1970.)

Age changed from Pliocene to late Pleistocene. (McDougall, 1969.)

Age changed from Early Permian (Leonard) to Early Permian (Wolfcamp). (Cooper and Grant, this report, p. A30.)

Port Refugio Formation adopted. (Eberlein and Churkin, 1970.)

Age changed from middle and late Tertiary to Oligocene. (Lipman and others, 1970.)

Prospect Mountain Quartzite restricted from Kingston Range and Clark Mountain area; replaced by (in ascending order): Johnnie, Stirling, Wood Canyon, and Zabriskie Formations. (Stewart, 1970.)

Age changed from post-Ordovician (?) to Precambrian. (Sainsbury and others, 1970.)

Pyramid Hill Sand of Wilson (1935) adopted as basal member of Jewett Sand. (Addicott, 1970.)

Quapaw Limestone adopted. (McKnight and Fischer, 1970.)

Rainstorm Member extended into southeastern California. (Stewart, 1970.)

Ra Jadero Member adopted. (Lipman and Steven, 1970.)

Age changed from Mississippian to Permian(?). (Brosgé and others, 1969.) Age changed from middle or late Tertiary to Oligocene. (Lipman and others, 1970.) 


\begin{tabular}{|c|c|c|}
\hline Name & Age & Location \\
\hline Rawley Andesite & Oligocene & Southwestern Colorado \\
\hline $\begin{array}{l}\text { Reeds Spring Member } \\
\text { (of Boone Formation). }\end{array}$ & Early Mississippian -- & Oklahoma \\
\hline Ringbone Shale & Late Cretaceous & New Mexico ___ \\
\hline Río Blanco Formation -- & Late Cretaceous & $\begin{array}{l}\text { Northwestern Puerto } \\
\text { Rico. }\end{array}$ \\
\hline $\begin{array}{l}\text { Río Culebrinas Forma- } \\
\text { tion. }\end{array}$ & Eocene & $\begin{array}{l}\text { Northwestern Puerto } \\
\text { Rico. }\end{array}$ \\
\hline Roadside Formation --_ & Late Cretaceous & Arizona - \\
\hline $\begin{array}{l}\text { Rock River Formation } \\
\text { (of Mesaverde Group). }\end{array}$ & Late Cretaceous _-_. & Wyoming _... \\
\hline
\end{tabular}

Roskruge Rhyolite _...-Round Mountain Silt

\section{Round Valley Peak} Granodiorite.

Rubio Peak Formation Ruby Star Granodiorite_

Russell Mountain Formation.

Sadlerochit Formation -

Sag River Sandstone ---

St. Joe Limestone Member (of Boone Formation).

St. Joseph Island Volcanics.

Salem Limestone

San Andres Limestone -

Sangre de Cristo Formation.

San Juan Formation --

San Ramon Sandstone -

Satanka Shale

Savanna Shale (of

Krebs Group).

Schieffelin Granodiorite -

Servilleta Formation

Shawangunk

Conglomerate.
Late Cretaceous

Arizona

middle Miocene

Late Cretaceous

Oligocene

Paleocene

Middle Silurian

Late Permian and Early Triassic.

Late Triassic

Early Mississippian --

Devonian(?)

Late Mississippian ---

Early Permian (Leonard).

Late Pennsylvanian and Early Permian.

Oligocene and older (?)

early Miocene(?)

Permian

Pennsylvanian

Late Cretaceous

Pliocene

Early and Middle Silurian.
California

Eastern California ---

New Mexico

Southern Arizona

Western Massachusetts

Northern Alaska

Northern Alaska

Oklahoma

Southeastern Alaska --

Eastern Kentucky ---

Northwestern New Mexico .

New Mexico and Colorado .

Southwestern Colorado

California

Colorado and Wyoming

Oklahoma and Kansas

Arizona

Colorado and New Mexico.

Eastern Pennsylvania and northeastern New Jersey . 
Revision and reference

Age changed from Miocene(?) to Oligocene. (Lipman and others, 1970.)

Name changed from Reeds Spring Chert Member to Reeds Spring Member. (McKnight and Fischer, 1970.)

Age changed from Early Cretaceous to Late Cretaceous. (Hayes, 1970a.)

Río Blanco Series of Hubbard (1923) adopted as Río Blanco Formation. (McIntyre and others, 1970.)

Río Culebrinas Series of Hubbard (1923) adopted and redefined as Río Culebrinas Formation. Overlies Mal Paso Formation (new). (McIntyre and others, 1970.)

Age changed from Mesozoic to Late Cretaceous. (Hayes, 1970a.)

Rock River Formation adopted as basal formation in Mesaverde Group along west flank of Laramie Basin. Does not occur east of Laramie Range and to west grades into Allen Ridge Formation of Mesaverde Group. (Gill and others, 1970.)

Age changed from Mesozoic to Late Cretaceous. (Hayes, 1970a.)

Round Mountain Silt of Diepenbrock (1933) adopted. Overlies Olcese Sand (new). (Addicott, 1970.)

Age changed from Cretaceous to Late Cretaceous. (Evernden and Kistler, 1970.)

Age changed from Miocene (?) to Oligocene. (Jones and others, 1970.)

Ruby Star Granodiorite of Livingston, Mauger, and Damon (1968) adopted. (Lovering and others, 1970.)

Russell Mountain Formation adopted. (Hatch and others, 1970.)

Age changed from Permian and Early Triassic to Late Permian and Early Triassic. (Detterman, 1970b.)

Sag River Sandstone of Fackler and others (1970) adopted. (Reiser, 1970.)

Age changed from Mississippian to Early Mississippian. (McKnight and Fischer, 1970.)

St. Joseph Island Volcanics adopted. (Eberlein and Churkin, 1970.)

Name changed from Salem Limestone to Salem Formation in eastern Kentucky. (Lewis and Luft, 1970.)

In Fort Wingate area, New Mexico, age changed from Early and Late Permian to Early Permian (Leonard). (Ash, 1969.)

Age changed from Pennsylvanian and Permian to Late Pennsylvanian and Early Permian. (Johnson, 1970.)

Age changed from Oligocene or older to Oligocene and older(?) (Lipman and others, 1970.)

Age changed from late Oligocene or early Miocene to early Miocene(?). (Addicott, 1970.)

Name changed from Satanka Shale to Satanka Formation in report area. (Braddock and others, 1970.)

Name changed from Savanna Formation to Savanna Shale in report area. Savanna Formation or Sandstone is good usage elsewhere. (McKnight and Fischer, 1970.)

Age changed from Late Cretaceous or Tertiary to Late Cretaceous. (Hayes, 1970a.)

Servilleta Formation of Montgomery (1953) adopted. (Lipman and others, 1970.)

In report area name changed to Formation and age changed from Silurian to Early and Middle Silurian. (Drake and others, 1969.) 


\begin{tabular}{ccc}
\hline Name & Age & Location \\
\hline
\end{tabular}

Shenango Formation ---

Shingle Creek Quartzite

Short Creek Oolite Member (of Boone Formation).

Sillem Member (of Fowkes Formation).

Silver Point Quartz Monzonite.

Skinner Ranch Formation.

Skokomish Gravel

Skolai Group

Skunk Ranch Conglomerate.

Snow Creek Porphyry --

Station Creek Formation

Sturgeon River Glaciation or Drift.

Sugarlump Tuff

Sullivan Peak Member (of Skinner Ranch Formation).

Sunset Member (of Bull Fork Formation).

Sunshine Peak Rhyolite_

Taft Granite

Talisay Member (of Alifan Limestone).

Tapeats Sandstone

Tapers Ranch Sandstone Member (of Haystack Mountains Formation) (of Mesaverde Group).

Tate Member (of Ashlock Formation).

Theresa Formation _..--

Thunder Springs Member (of Redwall Limestone).

Tilden Limestone Lentil (of Bingham Quartzite).

Tracy Creek Quartz Latite.
Mississippian

Pennsylvania and Ohio

late Precambrian

Late Mississippian

Eocene

Mesozoic(?)

Early Permian (Wolfcamp).

Pleistocene (Olympia Interglaciation).

Permian(?) and Permian.

Late Cretaceous

early Tertiary

Permian(?)

Pleistocene

Oligocene

Early Permian (Wolfcamp).

Late Ordovician

Oligocene

Late Jurassic

Miocene

Early Cambrian

Late Cretaceous

Late Ordovician

Late Cambrian and Early Ordovician.

Early Mississippian (Osage).

Pennsylvanian

Oligocene
Eastern Nevada and western Utah.

Oklahoma and Kansas

Southwestern Wyoming

Northeastern Washington.

Western Texas

West-central Washington.

Alaska

New Mexico

Montana

Alaska

Alaska

New Mexico

Western Texas

Northeastern

Kentucky.

Southwestern Colorado

Eastern California -..

Guam

Southeastern

California.

Wyoming

Northeastern Kentucky

Vermont and New York

Arizona

North-central Utah ...

Southwestern Colorado 
Revision and reference

Shenango Formation revised to include Shenango Formation, as previously used, as unnamed lower member and the Hempfield Shale (abandoned) as unnamed upper member. (Kimmel and Schiner, 1970.)

Shingle Creek Quartzite of Misch and Hazzard (1962) adopted. (Whitebread, 1969.)

Age changed from Mississippian to Late Mississippian. (McKnight and Fischer, 1970.)

Sillem adopted as basal member. Underlies Bulldog Hollow Member (new). (Oriel and Tracey, 1970.)

Silver Point Quartz Monzonite adopted. (Miller, 1969.)

Age changed from Early Permian (Leonard) to Early Permian (Wolfcamp). (Cooper and Grant, this report, p. A30.)

Skokomish Gravel adopted. (Molenaar and Noble, 1970.)

Skolai Group adopted. Includes (in ascending order) : Station Creek and Hasen Creek Formations (both new). (Smith and MacKevett, 1970.)

Age changed from Early Cretaceous to Late Cretaceous. (Hayes, 1970a.)

Age changed from post-Cretaceous(?) to early Tertiary. (Witkind and others, 1970.)

Station Creek adopted as lower of two formations in Skolai Group (new). Underlies Hasen Creek Formation (new). (Smith and MacKevett, 1970.)

Sturgeon River Glaciation or Drift adopted. (Karlstrom, 1969.)

Age changed from Miocene(?) to Oligocene. (Jones and others, 1970.)

Age changed from Early Permian (Leonard) to Early Permian (Wolfcamp). (Cooper and Grant, this report, p. A30.)

Sunset Member of Arnheim Formation of Foerste (1912) adopted as Sunset Member of Bull Fork Formation. (Outerbridge, 1970.)

Age changed from middle and late Tertiary to Oligocene. (Lipman and others, 1970.)

Age changed from Cretaceous to Late Jurassic. (Evernden and Kistler, 1970.)

Age changed from Miocene and Pliocene to Miocene. (Leopold, 1969.)

Strata of Tapeats Sandstone in Providence Mountains reassigned to Johnnie, Stirling, Wood Canyon, and Zabriskie Formations. (Stewart, 1970.)

Tapers Ranch Sandstone Member adopted as basal member of Haystack Mountains Formation in Hanna and Carbon basins. (Gill and others, 1970.)

Tate Member of Ashlock Formation in central Kentucky extended into northeastern Kentucky as Tate Member of Grant Lake Limestone. (Outerbridge, 1970.)

Name changed from Theresa Dolomite to Theresa Formation; age changed from Late Cambrian to Late Cambrian and Early Ordovician. (Cady, 1969.)

Age changed from Mississippian to Early Mississippian (Osage). (McKee and Gutschick, 1969.)

Tilden Limestone Lentil abandoned. Its rocks included in Butterfield Peaks Formation (new). (Tooker and Roberts, 1970.)

Age changed from Miocene(?) to Oligocene. (Lipman and others, 1970.) 


\begin{tabular}{lll}
\hline Name & Age & Location \\
\hline
\end{tabular}

Treasure Mountain Rhyolite.

Tunp Member (of Wasatch Formation).

Tuolumne Intrusive Series.

Tuscahoma Formation (of Wilcox Group).

Twilight Granite

Utica Shale

Vedder Sand

Vekol Formation

Vicksburg Group

Wachsmuth Limestone (of Lisburne Group).

Wadleigh Limestone

Wahoo Limestone (of Lisburne Group).

Walker Formation

Wallace Creek Tongue (of Cody Shale).

Waltersburg Formation/ Sandstone.

Wasatch Formation

West Canyon Limestone

West Elk Breccia

Whitehead Granite

White Knob Limestone -

White Mountain Plutonic Series.

Whiteside Granite

Whitmore Wash Member (of Redwall Limestone).

Wilcox Group
Oligocene

Southwestern Colorado

Eocene

Late Cretaceous

Southwestern Wyoming

California

Eocene

Mississippi

Precambrian

Southwestern Colorado Middle Ordovician Eastern New York -.-

early Miocene

California

Late Cretaceous

early Oligocene

Early and Late Mississippian.

Middle and Late Devonian.

Early and Middle

Pennsylvanian.

middle or late Eocene to early Miocene.

Late Cretaceous

Late Mississippian _--

Paleocene and Eocene - Southwestern Wyoming

Early Pennsylvanian

Oligocene and older(?)

Precambrian

Late Mississippian ---

Late Triassic or Early Jurassic.

Precambrian (?)

Early Mississippian

(Kinderhook and Osage).

Eocene
Kentucky

North-central Utah

\section{Arizona}

Louisiana, Alabama, and Mississippi.

Northern Alaska

Southeastern Alaska -

Northern Alaska

California

Wyoming

Southwestern Colorado

Southwestern Colorado

Idaho

New Hampshire

South Carolina and North Carolina.

Arizona

Mississippi 
Name changed to Treasure Mountain Tuff; includes (in ascending order): lower tuff, La Jara Canyon Member (new), middle tuff, Ojito Creek Member (new), Ra Jadero Member (new), and upper tuff. (Lipman and Steven, 1970.)

Tunp Member adopted. (Oriel and Tracey, 1970.)

Age changed from Cretaceous to Late Cretaceous. (Evernden and Kistler, 1970.)

Tuscahoma Formation of Wilcox Group used in central Mississippi. Previously the Wilcox Group had not been differentiated in this area. (Cushing and others, 1970.)

Name changed from Twilight Granite to Twilight Gneiss. (Barker, 1969.)

Age changed from Late Ordovician to Middle Ordovician in report area. Remains Late Ordovician elsewhere. (Cady, 1969.)

Vedder Sand as redefined by Diepenbrock (1933) adopted. When present: overlies Walker Formation; underlies Jewett Sand. (Addicott, 1970.)

Age changed from Late(?) Mesozoic to Late Cretaceous. (Hayes, 1970a.)

Age changed from middle Oligocene to early Oligocene. (Bukry, 1970.)

Age changed from Early Mississippian to Early and Late Mississippian. (Armstrong and others, 1970.)

Underlies the Peratrovich Formation of Early and Late Mississippian age. (Eberlein and Churkin, 1970.)

Age changed from Pennsylvanian(?) and Permian to Early and Middle Pennsylvanian. (Armstrong and others, 1970.)

Walker Formation of Wilhelm and Saunders (1927) adopted. Underlies Vedder Sand, when present, or Jewett Sand. (Addicott, 1970.)

Wallace Creek Tongue of Barwin (1961) adopted as upper member of Cody Shale in southeastern Wind River basin. Separated from main body of Cody by Fales Sandstone Member of Mesaverde Formation. (Gill and others, 1970.)

Waltersburg Formation/Sandstone reduced in rank to member of Buffalo Wallow Formation in north-central Kentucky. Remains of formation rank in Illinois and western Kentucky. (Goudarzi, 1970.)

In Fossil basin, Wasatch Formation is divided into seven units: basal conglomerate member, lower member, main body, sandstone tongue, mudstone tongue, B:allpen Member (new), and peripheral Tunp Member (new), which is equivalent to parts of upper five units. (Oriel and Tracey, 1970.)

West Canyon Limestone Member of Nygreen (1958) adopted and redefined as lowermost of three formations in Oquirrh Group in Bingham sequence (central and southern Oquirrh Mountains). Underlies Butterfield Peaks Formation (new). (Tooker and Roberts, 1970.)

Age changed from Oligocene or older to Oligocene and older(?). (Lipman and others, 1970.)

(Whitehead Granite abandoned. Its rocks included in Irving, Twilight, or Tenmile Formation, depending on location. (Barker, 1969.)

Age changed from Early Mississippian to Early Permian to Late Mississippian. (Skipp and Mamet, 1970.)

Name changed from White Mountain Plutonic-Volcanic Series to White Mountain Plutonic Series. (Cady, 1969.)

Age changed from Ordovician to Devonian to Precambrian(?). (Bryant and Reed, 1970.)

Age changed from Mississippian to Early Mississippian. (Kinderhook and Osage). (McKee and Gutschick, 1969.)

Wilcox Group in central Mississippi divided into Hatchetigbee, Tuscahoma, and Nanafalia Formations. (Cushing and others, 1970.) 


\begin{tabular}{|c|c|c|}
\hline Name & Age & Location \\
\hline Wood Canyon Formation & $\begin{array}{l}\text { Precambrian and Early } \\
\text { Cambrian. }\end{array}$ & $\begin{array}{l}\text { Southeastern California } \\
\text { and southern Nevada. }\end{array}$ \\
\hline $\begin{array}{l}\text { Yampa Limestone Lentil } \\
\text { (of Bingham } \\
\text { Quartzite). }\end{array}$ & Pennsylvanian & North-central Utah _... \\
\hline Zabriskie Quartzite _-.-- & Early Cambrian & $\begin{array}{l}\text { Southeastern California } \\
\text { and southern Nevada. }\end{array}$ \\
\hline $\begin{array}{l}\text { Zimmer Ridge } \\
\text { (of Oember } \\
\text { tion). }\end{array}$ & Precambrian & South Dakota ------- \\
\hline
\end{tabular}

\section{THE MIFFLINTOWN FORMATION OF MIDDLE SILURIAN AGE, BEDFORD COUNTY, PENNSYLVANIA}

By Wallace de WitT, JR.

Miller and Conlin (in Miller, 1961, p. 11) redefined the Mifflintown Limestone of Lesley (in Dewees, 1878, p. xxv-xxvi) to include the strata between the top of the Rose Hill Formation and the base of the Bloomsburg Red Beds in the Loysville quadrangle, Juniata and Perry Counties, Pa. They designated the Mifflintown a formation and recognized two mappable units: the Keefer Member overlain by the undivided Rochester and McKenzie Members.

Recent geologic mapping in the vicinity of Hyndman and Beans Cove in southwest Bedford County, Pa., demonstrated that the Mifflintown can be mapped in this area, and the formation as redefined by Miller and Conlin is herein adopted for use by the U.S. Geological Survey. The Mifflintown consists of 300-425 feet of soft calcareous shale, intercalated with thin-bedded lenticular fossiliferous limestone, and a small amount of sandstone, siltstone, and sandy hematite in the basal part. The formation is one of the least well exposed units in southwest Bedford County, and generally only the more resistant sandy beds of the basal Keefer Member as used by Miller and Conlin are exposed.

The twofold subdivision of the Mifflintown can be recognized; however, the basal Keefer is commonly too thin to be mapped at a scale of 1:24,000. Locally, in the northwest part of Beans Cove, the Keefer is as much as 25 feet thick, but generally it is about 10 feet thick. Because the Keefer is composed of resistant sandstone, siltstone, and silty mud rock, the unit commonly holds up a line of 
Revision and reference

Wood Canyon Formation extended to all rocks previously designated Daylight Formation. Also extended to Kingston Range and Clark Mountain area, California, at expense of Prospect Mountain Quartzite. As thus defined, generally overlies Stirling Quartzite and everywhere underlies Zabriskie Quartzite. (Stewart, 1970.)

Yampa Limstone Lentil abandoned. Its rocks included in Bingham Mine Formation. (Tooker and Roberts, 1970.)

Zabriskie Quartzite extended into Kingston Range, Clark Mountain area, and Providence Mountains. Everywhere overlies Wood Canyon Formation and underlies Carrara Formation. Includes all rocks previously designated Corkscrew Quartzite. (Stewart, 1970.)

Zimmer Ridge Member adopted. (Ratte and Wayland, 1969.)

small knobs that rise as much as $40-80$ feet topographically above the less resistant and more calcareous part of the steeply dipping Mifflintown.

In southern Bedford County, as in adjacent Allegany County, Md., the intercalated shale and thin-bedded limestone of the Rochester are lithologically indistinguishable from much of the overlying McKenzie (de Witt and Colton, 1964, p. 17). The two units can only be differentiated by their contained faunas. Meager paleontologic data suggest that the Rochester Member as used by Miller and Conlin may be as much as 35 feet thick in southwest Bedford County but is generally too thin to be mapped as a separate unit at a scale of $1: 24,000$. In contrast, the McKenzie Member as used by Miller and Conlin is more than 300 feet thick.

The base of the Mifflintown Formation, the lower boundary of the Keefer unit, is marked in southwest Bedford County by an abrupt change from medium-olive-gray silty shale of the underlying Rose Hill Formation to olive-gray calcareous siltstone, lenticular sandy hematite, and light-gray quartzitic sandstone. The top of the Keefer unit is generally covered by float and is rarely observed except in artificial exposures. The McKenzie unit of the Mifflintown is gradational into the overlying Bloomsburg Red Beds in a 10- to 15-foot zone of intercalated thin-bedded dark-gray lenticular limestone, olive-gray calcareous shale, light-greenish-gray silty shale, and grayish-red to purple silty mud rock. The boundary between the two formations is commonly placed at the base of a massive purple silty mud rock in the upper part of the transitional sequence. The boundary is generally marked by an abrupt change in soil color in cultivated fields and by an abundance of chips of reddish-brown and purple silty mud rock in wooded areas. 


\section{NEW AGE ASSIGNMENTS IN THE STRATIGRAPHY OF THE GLASS MOUNTAINS, WESTERN TEXAS}

By G. A. Cooper ${ }^{1}$ and R. E. Grant

Based on the preponderance of brachiopod evidence, the following new assignments are made in the stratigraphy of the Glass Mountains, western Texas: The upper part of the Gaptank Formais placed in the Wolfcamp Series as is the Skinner Ranch Formation. These assignments are based on early spasmodic presence of such Permian elements as Limbella (an aulostegid brachiopod), Scacchinella (a well-known Permian type), and Waagenoconcha in rocks formerly considered Late Pennsylvanian. These three and other Permian types became increasingly abundant in the famous Uddenites-bearing shale member of the Gaptank Formation, here placed at the bottom of the Permian. Many Pennsylvanian and Wolfcamp genera and the great biohermal assemblages of the Wolfcamp rocks culminated in the Skinner Ranch Formation, which represents the end of the Wolfcamp Series.

Faunas of the Road Canyon Formation have already been assigned to the Leonard Series by Cooper and Grant (1966), who regarded the preponderance of the fauna to be Leonard in generic content and general expression. Higher Word Formation assemblages are correlated with the Guadalupe type area as follows: Fossils of the China Tank Member (formerly Second Limestone Member) appear in the Cherry Canyon Formation; lower Getaway Limestone Member of the Cherry Canyon has the fauna of the Willis Ranch Member (Third Limestone Member of the Word of P. B. King) ; and upper Gateway contains fossils of the Appel Ranch Member (Fourth Limestone Member of the Word). The South Wells Member of the Cherry Canyon, a black shale and carbonate facies, seems not to be represented in the Glass Mountains. Bell Canyon Formation (Hegler Limestone Member) fossils have been found in undolomitized limestone at the base of the Capitan Limestone in the Glass Mountains.

Although these changes are based largely on brachiopods, they are in accordance with age indications of some other groups but not all.

${ }^{1}$ U.S. National Museum of Natural History, Smithsonian Institution, Washington, D.C. 20560 . 


\section{REFERENCES}

Addicott, W. O., 1970, Miocene gastropods and biostratigraphy of the Kern River area, California: U.S. Geol. Survey Prof. Paper 642, 174 p.

Armstrong, A. K., 1962, Stratigraphy and paleontology of the Mississippian system in southwestern New Mexico and adjacent southeastern Arizona: New Mexico Bur. Mines and Mineral Resources Mem. 8, 99 p.

1970, Mississippian stratigraphy and geology of the northwestern part of the Klondike Hills, southwestern New Mexico, in New Mexico Geol. Soc. Guidebook, 21st Field Conf.: p. 59-64.

Armstrong, A. K., Mamet, B. L., and Dutro, J. T., Jr., 1970, Foraminiferal zonation and carbonate facies of the Mississippian and Pennsylvanian Lisburne Group, central and eastern Brooks Range, Arctic Alaska: Am. Assoc. Petroleum Geologists Bull., v. 54, no. 5, p. 687-698.

Ash, S. R., 1969, Ferns from the Chinle Formation (Upper Triassic) in the Fort Wingate area, New Mexico: U.S. Geol. Survey Prof. Paper 613-D, p. D1-D52.

Bachman, G. O., and Harbour, R. L., 1970, Geologic map of northern part of San Andres Mountains, central New Mexico: U.S. Geol. Survey Misc. Geol. Inv. Map I-600.

Barker, Fred, 1969, Precambrian geology of the Needle Mountains, southwestern Colorado: U.S. Geol. Survey Prof. Paper 644-A, p. A1-A35.

Barwin, J. R., 1961, Stratigraphy of the Mesaverde Formation in the southern part of the Wind River Basin, Wyoming, in Symposium on Late Cretaceous rocks, Wyoming and adjacent areas, Wyoming Geol. Assoc., 16th Ann. Field Conf., 1961: Casper, Wyo., Petroleum Inf., p. 171-179.

Bergstrom, J. R., 1959, Generalized composite section of "Mesaverde" rocks of southeastern Wyoming, in Haun, J. D., and Weimer, R. J., eds., Symposium on Cretaceous rocks of Colorado and adjacent areas, Rocky Mtn. Assoc. Geologists, 11th Field Conf., Washakie, Sand Wash, and Piceance basins: p. 114.

Bolke, E. E., and Price, Don, 1969, Hydrologic reconnaissance of Curlew Valley, Utah and Idaho: Utah Dept. Nat. Resources Tech. Pub. 25, 40 p.

Brabb, E. E., and Churkin, Michael, Jr., 1969, Geologic map of the Charley River quadrangle, east-central Alaska: U.S. Geol. Survey Misc. Geol. Inv. Map I-573.

Braddock, W. A., Calvert, R. H., Gawarecki, S. J., and Nutalaya, Prinya, 1970, Geologic map of the Masonville quadrangle, Larimer County, Colorado: U.S. Geol. Survey Geol. Quad. Map GQ-832.

Brosgé, W. P., Lanphere, M. A., Reiser, H. N., and Chapman, R. M., 1969, Probable Permian age of the Rampart Group, central Alaska: U.S. Geol. Survey Bull. 1294-B, p. B1-B18.

Bryant, Bruce, and Reed, J. C., Jr., 1970, Structural and metamorphic history of the southern Blue Ridge, in Fisher, G. W., Pettijohn, F. J., Reed, J. C., Jr., and Weaver, Kenneth, eds., Studies of Appalachian geology-central and southern: New York, Intersci. Publishers, p. 213-225.

Bukry, David, 1970, Coccolith age determinations, Leg 2, Deep Sea Drilling Project, in Initial reports of the Deep Sea Drilling Project-Volume 2, Covering Leg 2 of the cruises of the Drilling Vessel "Glomar Challenger," Hoboken, N.J., to Dakar, Senegal, October-November 1968: Washington, U.S. Gov. Printing Office, p. 349-355.

Cady, W. M., 1969, Regional tectonic synthesis of northwestern New England and adjacent Quebec: Geol. Soc. America Mem. 120, 181 p. 
Cannon, W. F., and Gair, J. E., 1970, A revision of stratigraphic nomenclature for middle Precambrian rocks in northern Michigan: Geol. Soc. America Bull., v. 81, no. 9, p. 2843-2846.

Clifton, H. E., and Boggs, Sam, Jr., 1970, Concave-up pelecypod (Psephidia) shells in shallow marine sands, Elk River Beds, southwestern Oregon: Jour. Sed. Petrology, v. 40, no. 3, p. 888-897.

Cooper, G. A., and Grant, R. E., 1966, Permian rock units in the Glass Mountains, west Texas: U.S. Geol. Survey Bull. 1244-E, p. E1-E9.

Cragin, F. W., 1896, The Permian system in Kansas: Colorado Coll. Studies, v. 6, p. $1-48$.

Crandell, D. R., 1969, Surficial geology of Mount Rainer National Park, Washington: U.S. Geol. Survey Bull. 1288, 41 p.

Cressman, E. R., and Hrabar, S. V., 1970, Geologic map of the Wilmore quadrangle, central Kentucky: U.S. Geol. Survey Geol. Quad. Map GQ847.

Cross, C. W., Howe, Ernest, Irving, J. D., and Emmons, W. H., 1905, Description of the Needle Mountain quadrangle, Colorado: U.S. Geol. Survey Geol. Atlas Folio 131, 13 p.

Csejtey, Béla, Jr., 1970, Geologic map of the Nolansburg quadrangle, southeastern Kentucky: U.S. Geol. Survey Geol. Quad. Map GQ-868.

Cullins, H. C., 1969, Geologic map of the Mellen Hill quadrangle, Rio Blanco and Moffat Counties, Colorado: U.S. Geol. Survey Geol. Quad. Map GQ-835.

Cushing, E. M., Boswell, E. H., Speer, P. R., and Hosman, R. L., 1970, Availability of water in Mississippi embayment: U.S. Geol. Survey Prof. Paper 448-A, p. A1-A13.

Detterman, R. L., 1970a, Early Holocene warm interval in northern Alaska: Arctic, v. 23, no. 2, p. 130-132.

- 1970b, Sedimentary history of the Sadlerochit and Shublik Formations in northeastern Alaska, in Geological Seminar on the North Slope of Alaska, Palo Alto, Calif., 1970, Proceedings: Los Angeles, Calif., Am. Assoc. Petroleum Geologists, Pacific Sec., p. 0-1 to 0-13.

Dewees, J. H., 1878, Report of progress in the Juniata district on the fossil iron ore beds of middle Pennsylvania: Pennsylvania Geol. Survey, 2d, Rept. F, 139 p.

de Witt, Wallace, Jr., and Colton, G. W., 1964, Bedrock geology of the Evitts Creek and Pattersons Creek quadrangles, Maryland, Pennsylvania, and West Virginia: U.S. Geol. Survey Bull. 1173, 90 p.

Diepenbrock, Alex, 1933, Mount Poso oil field: California Oil Fields, v. 19, no. 2, p. 4-35.

Drake, A. A., Jr., Epstein, J. B., and Aaron, J. M., 1969, Geologic map and sections of parts of the Portland and Belvidere quadrangles, New Jersey and Pennsylvania: U.S. Geol. Survey Misc. Geol. Inv. Map I-552.

Dutro, T. W., Jr., 1970, Pre-Carboniferous carbonate rocks, northeastern Alaska, in Geological Seminar on the North Slope of Alaska, Palo Alto, Calif., 1970, Proceedings: Los Angeles, Calif., Am. Assoc. Petroleum Geologists, Pacific Sec.,p. M-1 to M-7.

Eberlein, G. D., and Churkin, Michael, Jr., 1970, Paleozoic stratigraphy in the northwest coastal area of Prince of Wales Island, southeastern Alaska: U. S. Geol. Survey Bull. 1284, 67 p.

Elston, W. E., 1957, Geology and mineral resources of Dwyer quadrangle, 
Grant, Luna, and Sierra Counties, New Mexico: New Mexico Bur. Mines and Mineral Resources Bull. 38, 86 p.

Ericksen, G. E., Wedow, Helmuth, Jr., Eaton, G. P., and Leland, G. R., 1970, Mineral resources of the Black Range Primitive Area, Grant, Sierra, and Catron Counties, New Mexico: U.S. Geol. Survey Bull. 1319-E, p. E1E162.

Espenshade, G. H., 1970, Geology of the northern part of the Blue Ridge anticlinorium, in Fisher, G. W., Pettijohn, F. J., Reed, J. C., Jr., and Weaver, Kenneth, eds., Studies of Appalachian geology - central and southern: New York, Intersci. Publishers, p. 199-211.

Evernden, J. F., and Kistler, R. W., 1970, Chronology of emplacement of Mesozoic batholithic complexes in California and western Nevada: U.S. Geol. Survey Prof. Paper 623, 42 p.

Fackler, W. C., and others, 1970, The Sag River Sandstone and Kuparuk River sands, two important subsurface units in the Prudhoe Bay Field, in Geological Seminar on the North Slope of Alaska, Palo Alto, Calif., 1970, Proceedings: Los Angeles, Calif., Am. Assoc. Petroleum Geologists, Pacific Sec., p. P-1 to $\mathrm{P}-3$.

Foerste, A. F., 1912, The Arnheim Formation within the areas traversed by the Cincinnati geanticline: Ohio Naturalist, v. 12 , no. 3, p. 429-456.

Gill, J. R., Merewether, E. A., and Cobban, W. A., 1970, Stratigraphy and nomenclature of some Upper Cretaceous and lower Tertiary rocks in south-central Wyoming: U.S. Geol. Survey Prof. Paper 667, 53 p.

Godde, H. A., 1928, Miocene formations in the east side fields of Kern County: California Oil Fields, v. 14, no. 1, p. 5-15.

Goudarzi, G. H., 1970, Geologic map of the Glen Dean quadrangle, Breckinridge and Hancock Counties, Kentucky: U.S. Geol. Survey Geol. Quad. Map GQ-836.

Gregory, H. E., 1906, The crystalline rocks [of Connecticut]: Connecticut Geol. and Nat. History Survey Bull. 6, p. 39-156.

Hale, L. A., 1961, Late Cretaceous (Montanan) stratigraphy, eastern Washaki Basin, Carbon County, Wyoming, in Symposium on Late Cretaceous rocks, Wyoming and adjacent areas, Wyoming Geol. Assoc., 16th Ann. Field Conf., 1961: Casper, Wyo., Petroleum Inf., p. 129-137.

Hall, C. A., Turner, D. L., and Surdham, R. C., 1966, Potassium-argon age of the Obispo Formation with Pecten lompocensis Arnold, southern Coast Range, California: Geol. Soc. America Bull., v. 77, no. 4, p. 443-445.

Hansen, W. R., 1969, The geologic story of the Uinta Mountains: U.S. Geol. Survey Bull. 1291, 144 p.

Harris, L. D., and Mixon, R. B., 1970, Geologic map of the Howard Quarter quadrangle, northeastern Tennessee: U.S. Geol. Survey Geol. Quad. Map GQ-842.

Hatch, N. L., Jr., 1969, Geology of the Worthington quadrangle, Hampshire and Berkshire Counties, Massachusetts: U.S. Geol. Survey Geol. Quad. Map GQ-857.

Hatch, N. L., Jr., Stanley, R. S., and Clark, S. F., Jr., 1970, The Russell Mountain Formation, a new stratigraphic unit in western Massachusetts: U.S. Geol. Survey Bull. 1324-B, p. B1-B10.

Hayes, P. T., 1970a, Cretaceous paleogeography of southeastern Arizona and adjacent areas: U.S. Geol. Survey Prof. Paper 658-B, p. B1-B42.

1970b, Mesozoic stratigraphy of the Mule and Huachuca Mountains, Arizona: U.S. Geol. Survey Prof. Paper 658-A, p. A1-A28. 
Hietanen, Anna, 1968, Metamorphic environment of anorthosite in the Boehls Butte area, Idaho, in Origin of anorthosite and related rocks: New York State Mus. and Sci. Service Mem. 18, p. 371-386.

Hintze, L. F., 1951, Lower Ordovician detailed stratigraphic sections for western Utah: Utah Geol. and Mineralog. Survey Bull. 39, 100 p.

Hubbard, Bela, 1923, The geology of the Lares district, Porto Rico: New York Acad. Sci., Sci. Survey of Porto Rico and the Virgin Islands, v. 2, pt. 1, p. 1-115.

Izett, G. A., Denson, N. M., and Obradovich, J. D., 1970, K-Ar age of the lower part of the Browns Park Formation, northwestern Colorado, in Geological Survey research 1970: U.S. Geol. Survey Prof. Paper 700-C, p. C150-C152.

Johnson, R. B., 1970, Geologic map of the Villanueva quadrangle, San Miguel County, New Mexico: U.S. Geol. Survey Geol. Quad. Map GQ-869.

Jones, D. L., Bailey, E. H., and Imlay, R. W., 1969, Structural and stratigraphic significance of the Buchia zones in the Colyear Springs-Paskenta area, California: U.S. Geol. Survey Prof. Paper 647-A, p. A1-A24.

Jones, W. R., Moore, S. L., and Pratt, W. P., 1970, Geologic map of the Fort Bayard quadrangle, Grant County, New Mexico: U.S. Geol. Survey Geol. Quad. Map GQ-865.

Karlstrom, T. N. V., 1969, Regional setting and geology, Chapter 2 in Karlstrom, T. N. V., and Ball, G. E., eds., The Kodiak Island refugium, its geology, flora, fauna and history: Toronto, Ontario, Ryerson Press (for Boreal Inst., Univ. Alberta), p. 20-54.

Kimmel, G. E., and Schiner, G. R., 1970, The Shenango Formation (Mississippian) in northwestern Pennsylvania: U.S. Geol. Survey Bull. 1294-C, p. C1-C13.

King, E. R., Harrison, J. E., and Griggs, A. B., 1970, Geologic implications of aeromagnetic data in the Pend Orielle area, Idaho and Montana: U.S. Geol. Survey Prof. Paper 646-D, p. D1-D17.

Kleinpell, R. M., 1938, Miocene stratigraphy of California: Tulsa, Okla., Am. Assoc. Petroleum Geologists, $450 \mathrm{p}$.

Leopold, E. B., 1969, Miocene pollen and spore flora of Eniwetok Atoll, Marshall Islands: U.S. Geol. Survey Prof. Paper 260-II, p. 1133-1185 [1970].

Lewis, G. E., 1968, Stratigraphic paleontology of the Barstow Formation in the Alvord Mountain area, San Bernardino County, California, in Geological Survey research 1968: U.S. Geol. Survey Prof. Paper 600-C, p. C75-C79.

Lewis, R. Q., Sr., and Luft, S. J., 1970, Geologic map of the Parnell quadrangle, Wayne County, Kentucky: U.S. Geol. Survey Geol. Quad. Map GQ-861.

Lipman, P. W., and Steven, T. A., 1970, Reconnaissance geology and economic significance of the Platoro caldera, southeastern San Juan Mountains, Colorado, in Geological Survey research 1970: U.S. Geol. Survey Prof. Paper 700-C, p. C19-C29.

Lipman, P. W., Steven, T. A., and Mehnert, H. H., 1970, Volcanic history of the San Juan Mountains, Colorado, as indicated by potassium-argon dating: Geol. Soc. America Bull., v. 81, no. 8, p. 2329-2352.

Livingston, D. E., Mauger, R. L., and Damon, P. E., 1968, Geochronology of the emplacement, enrichment, and preservation of Arizona porphyry copper deposits: Econ. Geology, v. 63, no. 1, p. 30-36. 
Love, J. D., 1970, Cenozoic geology of the Granite Mountains area, central Wyoming: U.S. Geol. Survey Prof. Paper 495-C, p. C1-C154.

Lovering, T. G., Cooper, J. R., Drewes, Harald, and Cone, G. C., 1970, Copper in biotite from igneous rocks in southern Arizona as an ore indicator, in Geological Survey research 1970: U.S. Geol. Survey Prof. Paper 700-B, p. B1-B8.

Luft, S. J., 1970, Geologic map of the De Mossville quadrangle, north-central Kentucky: U.S. Geol. Survey Geol. Quad. Map GQ-862.

MacKevett, E. M., Jr., 1970, Geologic map of the McCarthy C-4 quadrangle, Alaska: U.S. Geol. Survey Geol. Quad. Map GQ-844.

Mattson, P. H., 1960, Geology of the Mayagües area, Puerto Rico: Geol. Soc. America Bull., v. 71, no. 3, p. 319-361.

McDougall, Ian, 1969, Potassium-argon ages on lavas of Kohala Volcano, Hawaii: Geol. Soc. America Bull., v. 80, no. 12, p. 2597-2600.

McIntyre, D. H., Aaron, J. M., and Tobisch, O. T., 1970, Cretaceous and lower Tertiary stratigraphy in northwestern Puerto Rico: U.S. Geol. Survey Bull. 1294-D, p. D1-D16.

McKee, E. D., and Gutschick, R. C., 1969, Sequence of sediments and unconformaties, Chapter 2 of History of the Redwall Limestone of northern Arizona: Geol. Soc. America Mem. 114, p. 13-95.

McKee, E. H., 1970, Fish Creek Mountains Tuff and volcanic center, Lander County, Nevada: U.S. Geol. Survey Prof. Paper 681, 17 p.

McKnight, E. T., and Fischer, R. P., 1970, Geology and ore deposits of the Picher field, Oklahoma and Kansas: U.S. Geol. Survey Prof. Paper 588, $165 \mathrm{p}$.

Meyer, W. R., Gutentag, E. D., and Lobmeyer, D. H., 1970, Geohydrology of Finney County, southwestern Kansas: U.S. Geol. Survey Water-Supply Paper 1891, 117 p.

Miller, F. K., 1969, Preliminary geologic map of the Loon Lake quadrangle, Stevens and Spokane Counties, Washington: Washington Div. Mines and Geology Geol. Map GM-6.

- 1970, Geologic map of the Quartzite quadrangle, Yuma County, Arizona: U.S. Geol. Survey Geol. Quad. Map GQ-841.

Miller, J. T., 1961, Geology and mineral resources of the Loysville quadrangle, Pennsylvania: Pennsylvania Geol. Survey, 4th ser., Topog. and Geol. Atlas A 127, 47 p.

Misch, Peter, and Hazzard, J. C., 1962, Stratigraphy and metamorphism of Late Precambrian rocks in central northeastern Nevada and adjacent Utah: Am. Assoc. Petroleum Geologists Bull., v. 46, no. 3, p. 289-343.

Molenaar, Dee, and Noble, J. B., 1970, Geology and related ground-water occurrence, southeastern Mason County, Washington: Washington Dept. Water Resources Water-Supply Bull. 29, 145 p.

Montgomery, Arthur, 1953, Pre-Cambrian geology of the Picuris Range, north-central New Mexico: New Mexico Bur. Mines and Mineral Resources Bull. 30,89 p.

Moore, J. G., 1969, Geology and mineral deposits of Lyon, Douglas, and Ormsby Counties, Nevada: Nevada Bur. Mines Bull. 75, 44 p.

Mutschler, F. E., 1970, Geologic map of the Snowmass Mountain quadrangle, Pitkin and Gunnison Counties, Colorado: U.S. Geol. Survey Geol. Quad. Map GQ-853. 
Nelson, W. H., and Ross, C. P., 1969, Geologic map of the Mackay quadrangle, south-central Idaho: U.S. Geol. Survey Misc. Geol. Inv. Map I-580.

Nygreen, P. W., 1958, The Oquirrh formation-stratigraphy of the lower portion in the type area and near Logan, Utah: Utah Geol. and Mineralog. Survey Bull. 61, 67 p.

Oriel, S. S., and Tracey, J. I., Jr., 1970, Uppermost Cretaceous and Tertiary stratigraphy of Fossil basin, southwestern Wyoming: U.S. Geol. Survey Prof. Paper 635, 53 p.

O'Sullivan, R. B., 1970, The upper part of the Upper Triassic Chinle Formation and related rocks, southeastern Utah and adjacent areas: U.S. Geol. Survey Prof. Paper 644-E, p. E1-E22.

Outerbridge, W. F., 1970, Geologic map of the Sherburne quadrangle, northeastern Kentucky: U.S. Geol. Survey Geol. Quad. Map GQ-854.

Ovenshine, A. T., and Webster, G. D., 1970, Age and stratigraphy of the Heceta Limestone in northern Sea Otter Sound, southeastern Alaska, in Geological Survey research 1970: U.S. Geol. Survey Prof. Paper 700-C, p. C170-C174.

Owens, J. P., Minard, J. P., Sohl, N. F., and Mello, J. F., 1970, Stratigraphy of the outcropping post-Magothy Upper Cretaceous formations in southern New Jersey and northern Delmarva Peninsula, Delaware and Maryland: U.S. Geol. Survey Prof. Paper 674, 60 p.

Parker, R. L., and Sharp, W. N., 1970, Mafic-ultramafic igneous rocks and associated carbonatites of the Gem Park Complex, Custer and Fremont Counties, Colorado: U.S. Geol. Survey Prof. Paper 649, 24 p.

Peck, J. H., 1969, Geologic map of the Flemingsburg quadrangle, Fleming and Mason Counties, Kentucky: U.S. Geol. Survey Geol. Quad. Map GQ-837.

Rankin, D. W., 1970, Stratigraphy and structure of Precambrian rocks in northwestern North Carolina, in Fisher, G. W., Pettijohn, F. J., Reed, J. C., Jr., and Weaver, Kenneth, eds., Studies of Appalachian geologycentral and southern: New York, Intersci. Publishers, p. 227-245.

Ratte, J. C., and Wayland, R. G., 1969, Geology of the Hill City quadrangle, Pennington County, South Dakota-A preliminary report: U.S. Geol. Survey Bull. 1271-B, p. B1-B14.

Reiser, H. N., 1970, Northeastern Brooks Range-a surface expression of the Prudhoe Bay section, in Geological Seminar on the North Slope of Alaska, Palo Alto, Calif., 1970, Proceedings: Am. Assoc. Petroleum Geologists, Pacific Sec., p. K-1 to K-13.

Sainsbury, C. L., Coleman, R. G., and Kachadoorian, Reuben, 1970, Blueschist and related greenschist facies rocks of the Seward Peninsula, Alaska, in Geological Survey research 1970: U.S. Geol. Survey Prof. Paper 700-B, p. B33-B42.

Scholl, D. W., Greene, H. G., and Marlow, M. S., 1970, Eocene age of the Adak "Paleozoic(?)" rocks, Aleutian Islands, Alaska: Geol. Soc. America Bull., v. 81, no. 12, p. 3583-3592.

Scott, G. R., 1970, Quaternary faulting and potential earthquakes in eastcentral Colorado, in Geological Survey research 1970: U.S. Geol. Survey Prof. Paper 700-C, p. C11-C18.

Skipp, Betty, and Mamet, B. L., 1970, Stratigraphic micropaleontology of the type locality of the White Knob Limestone (Mississippian), Custer 
County, Idaho, in Geological Survey research 1970: U.S. Geol. Survey Prof. Paper 700-B, p. B118-B123.

Smith, J. G., and MacKevett, E. M., Jr., 1970, The Skolai Group in the McCarthy B-4, C-4, and C-5 quadrangles, Wrangell Mountains, Alaska: U.S. Geol. Survey Bull. 1274-Q, 26 p.

Snyder, G. L., 1970, Bedrock geologic and magnetic maps of the Marlborough quadrangle, east-central Connecticut: U.S. Geol. Survey Geol. Quad. Map GQ-791, 2 sheets.

Stewart, J. H., 1970, Upper Precambrian and Lower Cambrian strata in the southern Great Basin, California and Nevada: U.S. Geol. Survey Prof. Paper 620, 206 p.

Stockdale, P. B., 1939, Lower Mississippian rocks of the east-central interior: Geol. Soc. America Spec. Paper 22, 248 p.

Stokes, W. L., 1944, Morrison Formation and related deposits in and adjacent to the Colorado Plateau: Geol. Soc. America Bull., v. 55, no. 8, p. 951-992.

Stoyanow, A. A., 1926, Notes on recent stratigraphic work in Arizona: Am. Jour. Sci., 5th ser., v. 12, p. 311-324.

Swanson, D. A., 1969, Reconnaissance geologic map of the east half of the Bend quadrangle, Crook, Wheeler, Jefferson, Wasco, and Deschutes Counties, Oregon: U.S. Geol. Survey Misc. Geol. Inv. Map I-568.

Tooker, E. W., and Roberts, R. J., 1970, Upper Paleozoic rocks in the Oquirrh Mountains and Bingham mining district, Utah: U.S. Geol. Survey Prof. Paper 629-A, 76 p.

Turner, D. L., Surdham, R. C., and Hall, C. A., 1970, The Obispo Formation and associated volcanic rocks in the central California Coast Ranges$\mathrm{K}-\mathrm{Ar}$ ages and biochronologic significance [abs]: Geol. Soc. America Abs. with Programs, v. 2, no. 2, p. 155.

Van Alstine, R. E., 1969, Geology and mineral deposits of the Poncha Springs NE quadrangle, Chaffee County, Colorado: U.S. Geol. Survey Prof. Paper 626, $52 \mathrm{p}$.

Vedder, J. G., 1970, Geologic map of the Wells Ranch and Elkhorn Hills quadrangles, San Luis Obispo and Kern Counties, California, showing juxtaposed Cenozoic rocks along the San Andreas fault: U.S. Geol. Survey Misc. Geol. Inv. Map I-585.

Vine, J. D., 1969, Geology and coal resources of the Cumberland, Hobart, and Maple Valley quadrangles, King County, Washington: U.S. Geol. Survey Prof. Paper 624, $67 \mathrm{p}$.

Vine, J. D., and Tourtelot, E. B., 1969, Geochemical investigations of some black shales and associated rocks: U.S. Geol. Survey Bull. 1314-A, p. A1-A43.

Welsh, J. E., and James, A. H., 1961, Pennsylvanian and Permian stratigraphy of the central Oquirrh Mountains, Utah, in Geology of the Bingham mining district and northern Oquirrh Mountains: Utah Geol. Soc. Guidebook to the Geology of Utah, no. 16, p. 1-16.

Whitebread, D. H., 1969, Geologic map of the Wheeler Peak and Garrison quadrangles, Nevada and Utah: U.S. Geol. Survey Misc. Geol. Inv. Map I-578.

Wilhelm, V. H., and Saunders, L. W., 1927, Report on the Mt. Poso oil field: California Oil Fields, v. 12, no. 7, p. 5-12.

Willden, Ronald, and Kistler, R. W., 1969, Geologic map of the Jiggs quadrangle, Elko County, Nevada: U.S. Geol. Survey Geol. Quad. Map GQ859. 
Wilson, L. E., 1935, Miocene marine mammals from the Bakersfield region, California: Peabody Mus. Nat. History Bull., v. 4, p. 1-143.

Witkind, I. J., Kleinkopf, M. D., and Keefer, W. R., 1970, Geologic and gravity evidence for a buried pluton, Little Belt Mountains, central Montana, in Geological Survey research 1970: U.S. Geol. Survey Prof. Paper 700-B, p. B63-B65. 

